$$
32^{5}+25-6 \text { MASTER }
$$
ORNL-3227
UC-10-Chemical Separations Processes for Plutonium and Uranium

TID -4500 (17th ed.)

\title{
COMPARATIVE COST STUDY OF PROCESSING \\ STAINLESS STEEL-JACKETED UO 2 FUEL: \\ MECHANICAL SHEAR-LEACH VS SULFEX-CORE \\ DISSOLUTION
}
J. B. Adams
A. M. Ben is
C. D. Watson

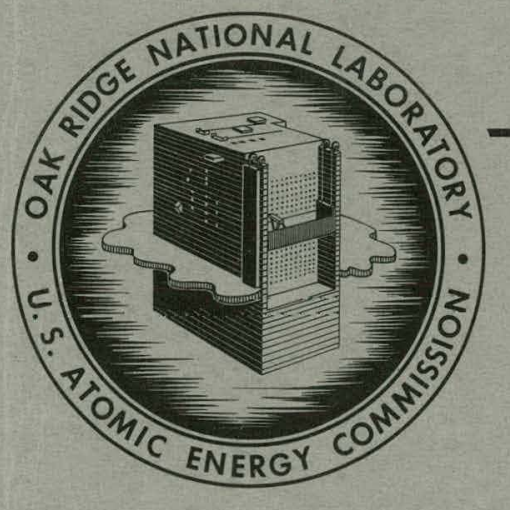

OAK RIDGE NATIONAL LABORATORY

$$
\text { operated by }
$$

UNION CARBIDE CORPORATION

$$
\text { for the }
$$

U.S. ATOMIC ENERGY COMMISSION 


\section{DISCLAIMER}

This report was prepared as an account of work sponsored by an agency of the United States Government. Neither the United States Government nor any agency Thereof, nor any of their employees, makes any warranty, express or implied, or assumes any legal liability or responsibility for the accuracy, completeness, or usefulness of any information, apparatus, product, or process disclosed, or represents that its use would not infringe privately owned rights. Reference herein to any specific commercial product, process, or service by trade name, trademark, manufacturer, or otherwise does not necessarily constitute or imply its endorsement, recommendation, or favoring by the United States Government or any agency thereof. The views and opinions of authors expressed herein do not necessarily state or reflect those of the United States Government or any agency thereof. 


\section{DISCLAIMER}

Portions of this document may be illegible in electronic image products. Images are produced from the best available original document. 
Printed in USA. Price $\$ 1,50$ cents. Available from the

Office of Technical Services

U. S. Department of Commerce

Washington 25, D. C.

\begin{abstract}
LEGAL NOTICE
This report was prepared as an account of Government sponsored work. Neither the United States, nor the Commission, nor any person acting on behalf of the Commission:

A. Makes any warranty or representation, express or implied, with respect to the accuracy, completeness, or usefulress of the information contained in this report, or that the use of any information, apparatus, method, or process disclosed in this report may not infringe privotely owned rights; or

B. Assumes any liabilities with respect to the use of, or for damages resulting from the use of any information, apparatus, method, or process disclosed in this report.

As used in the above, "person octing on behalf of the Commission" includes any employee or contractor of the Commission to the extent that such employee or contractor propares, handles or distributes, or provides access to, any information pursuant to his employment or contract with the Commission.
\end{abstract}


ORNL-3227

Contract No. W-7405-eng-26

Chemical Technology Division

COMPARATIVE COST STUDY OF PROCESSING STAINLESS STEEL-JACKETED UO 2 FUEL: MECHANICAL SHEAR-LEACH VS SULFEX-CORE DISSOLUTION
J. B. Adams
A. M. Benis
C. D. Watson

DATE ISSUED

MPR 23996

OAK RIDGE NATIONAL LABORATORY

Oak Ridge, Tennessee

operated by

UNION CARBIDE CORPORATION

for the

U. S: Atomic Energy Commission 


\section{ABSTRACT}

The economics of mechanical shear-leach and Sulfex decladding-core dissolution head end treatments for processing typical tubular bundles of stainless steel-jacketed $\mathrm{UO}_{2}$ nuclear fuels were compared. A 2.66 metric ton $U /$ day head end portion of a plant was designed for each process and capital and operating costs were developed. For plants of this size and larger, mechanical shear-leach processing has the advantage of 20\% lower capital cost and 50\% lower operating cost. Processing costs of stainless steel-jacketed $\mathrm{UO}_{2}$ by the Sulfex and shear-leach methods, including amötization and waste disposal but excluding solvent extraction, were $\$ 15.78$ and $\$ 2.71$ per kilogram of uranium, respectively. Storage of stainless steel waste produced by the shear-leach method is less costly by a factor of 20 than for Sulfex. 


\section{CONTENTS}

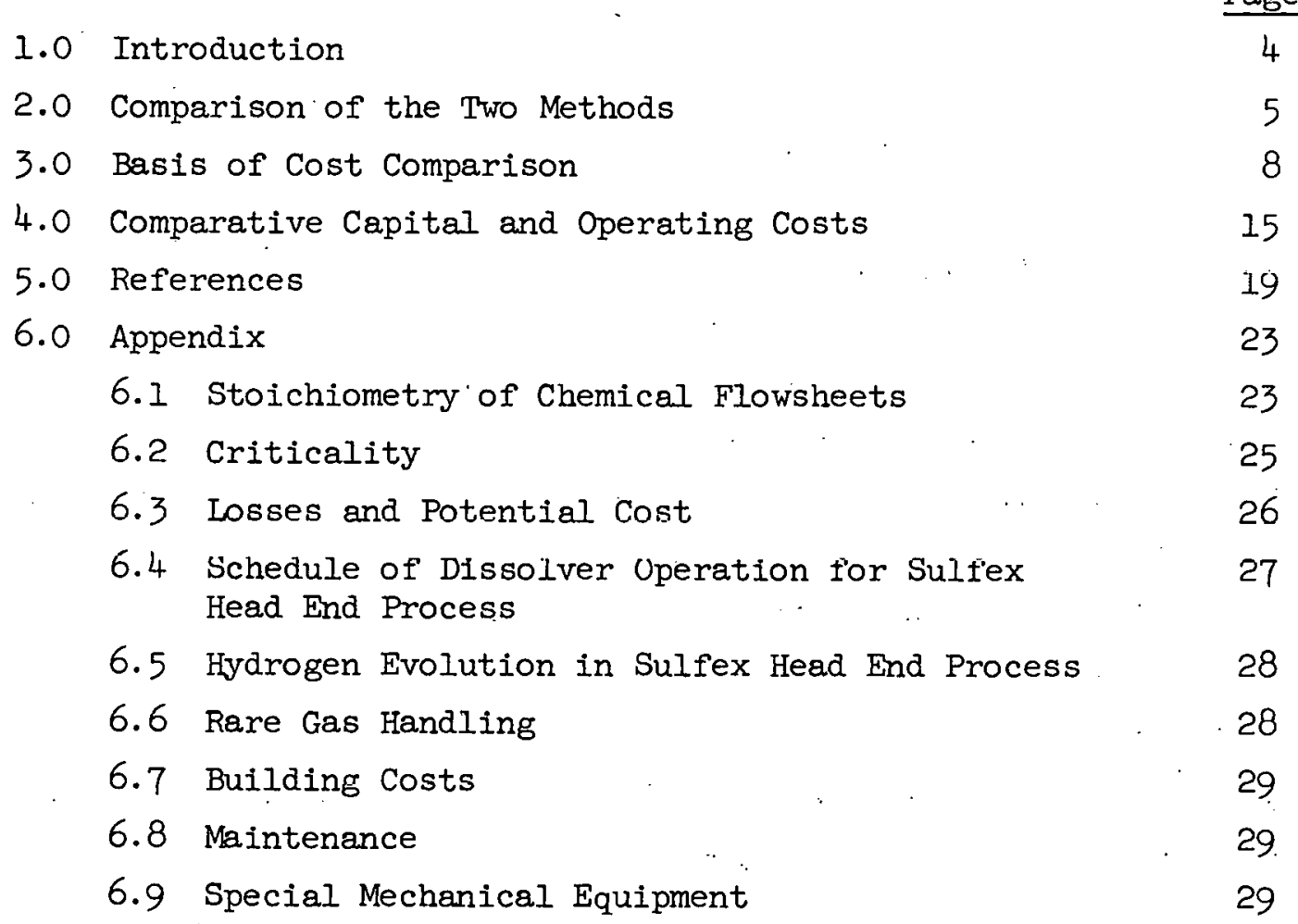

4 5 


\subsection{INTRODUCTION}

This report is an economic comparison of a mechanical head-end method, shear-leach, as developed at Oak Ridge National Laboratory, ${ }^{I}$ with a more conventional proposed, aqueous method, Sulfex, initially developed at Oak Ridge National Laboratory, ${ }^{2,3}$ for processing stainless steel-jacketed $\mathrm{UO}_{2}$ or uranium metal fuel. The comparison should help indicate the direction of further fuel processing development work, especially mechanical processing in which past development work has been much less extensive than in aqueous techniques. In the shear-leach process, cropped complete fuel. assemblies or subassemblies are sheared into short lengths, exposing the $\mathrm{UO}_{2}$ core from which the uranium is leached with boiling nitric acid. In the Sulfex process, the stainless steel jacket is dissolved in sulfuric acid, and discarded, and the exposed core is dissolved in nitric acid. In each case, the nitric acid solution would then be processed by known, proved methods.

The attainment of economic nuclear power in the U. S. depends partly on the development of cheap methods of recovering fissile and fertile materials from spent fuel. Extensive laboratory and development work on various methods, especially aqueous ones, has been done at ORNL, Hanford, Savannah River, and Idaho. Such work has been aimed mostly at providing an interim processing method for the large number of fuel assemblies that have resulted from attempts to produce economic nuclear power. Most such fuels consist of ceramic oxide cores of $\mathrm{UO}_{2}$ or $\mathrm{UO}_{2}-\mathrm{ThO}_{2}$ jacketed in Zircaloy-2 or stainless steel tubing, with the tubes fixed into a spaced array in a bundle. In general, the cores are soluble in nitric acid, but the jackets are insoluble, and most proposed processes involve dissolving the jacket in one reagent and disposing of it as a large-volume intermediate-activity waste, followed by dissolution of the core in nitric acid. All aqueous dejacketing-core dissolution processes are batch processes.

The shear-leach process appears to offer the economic advantages of large-scale continuous operation with a potentially small volume of solid metal waste. It is versatile and may be suitable for stainless steelor Zircaloy-2 jacketed ceramic oxide or liquid-metal-bonded fuels, and carbide core fuels. Although the equipment is expensive and probably would 
operate below capacity in a small plant, if fuel development leads to more exotic refractory jacketing materials, mechanical processing may be esisential.

The plant for each of the processes compared is a large, essentially single-purpose unit, although.with some changes either could process several other common types of fuels. The comparison is based on reclaiming uranium and plutonium from a common reactor fuel type, tubular bundles of stainless steel-jacketed $\mathrm{UO}_{2}$. With data from incomplete laboratoryand engineering-scale development work, a process flowsheet and plant design were prepared for each process for a plant with a capacity of 2.66 metric tons of uranium per operating day. Capital and operating costs were estimated for both methods, limited to the parts of the process that are different. This procedure was selected to prevent masking of cost differences by the large costs for the major part of the plant, i.e., the receiving facilities, canal storage, off-gas handling, feed-adjustment, solvent-extraction, solvent-cleanup, acid-recovery, high-activity waste disposal from the solvent extraction step, building ventilation, utilities, etc., which are essentially identical for the two processes.

Acknowledgment. The authors gratefully acknowledge the assistance of W. G. Stockdale for reviewing and assisting in the cost estimates, C. H. Odom, W. F. Schaffer, Jr., A. E. Spaller for head-end design assistance, H. E. Goeller and J. W. UlImann for review work.

\subsection{COMPARISON OF TIE TWO METHODS}

An economic comparison of the capital and operating costs for the nonidentical parts of a mechanical shear-leach w1th those of a Sulfex decladding-core dissolution head-end plant for processing stainless șteelclad $\mathrm{UO}_{2}$ fuel assemblies at a rate of 800 metric tons $\mathrm{U} /$ year shows that both capital and operating cusls are lower for the mechanical process: 
Capital cost, \$

Operating costs, $\$ / y r$

Mechanical

Sulfex

Shear-Leach

without amortization

$5,373,305$

$4,096,153$

6.7 yr amortization

Processing cost, $\$ / \mathrm{kg} U$ (including amortization)

\section{$2,247,452$}

$1,074,161$

$3,019,981$

$1,695,103$

2.12

The head-end plant considered includes process equipment, piping, construction, amortization, etc. but no items common and/or equal in the two designs, $i . e$. process canyon, receiving and storage areas, preparation facilities, dissolver off-gas handling, rare gas system (if used), or solvent extràction.

Based on 20 years' waste tank filling time, the economic advantage of the mechanical shear-leach head-end process is 20 to 1 :

Mechanical

Sulfex Shear-Leach

Initial investment cost, $\$$

Operating cost, $\$ /$ yr

Perpetual operating cost, $\$ / \mathrm{yr}$

Cost of waste storage, $\$ / \mathrm{kg} U$ processed

$\$ /$ gal of waste stored

Waste storage volume requirèd, gal/yr

$\begin{array}{cc} & 253,400 \\ 9,560,000 & 473,010 \\ - & 90,000 \\ 12.00 & 0.59 \\ 2.00^{4} & 4.98\end{array}$

Waste disposal costs for the high-activity waste from solvent extraction processing of the core are identical for the two plants.

The capital cost for a complete Sulfex plant of this size is guessed 5 to be of the order of $\$ 50$ million, so that the difference in capital (\$1:13 million) between the two head-end processes corresponds to about $2 \%$ of the total cost for a complete fuel processing plant.

The key difference between these large-throughput plants is the waste type, volume, and handling facilities. In the mechanical dejacketing waste, most of the hazardous radioactive material is fixed in the metal, greatly decreasing the possibility of escape of radioactive nuclides to the biological environment. The tankage volume required, the cost of the storage container, and the hazards due to corrosion and leakage over a long storage period are lower than for Sulfex waste. Also, the preparation and handling of Sulfex waste slurries require a large amount of in-cell floor space, tankage, pumps, and transfer lines as well as neutralization reagents. 
All these advantages should accrue to applicable mechanical processes in general compared to aqueous processes operating on identical fuel types.

There are other characteristic differences. Sulfex, like other aqueous processing systems where jacket and core are dissolved in separate reagents, is essentially a batch process and is limited to this by fuel element geometry, criticality, and the requirement that hydrogen and nitrogen oxides be kept separated. High-throughput plants must be made up of multiple units operating in parallel to obtain the desired production rate. Mechanical shear-leach processing is essentially continuous and can expose the fuel cores of many types of fuel, independently of the jacketing material, allowing recovery of fissionable material by methods that use stainless steel equipment. Scaleup of Sulfex does not decrease costs but mechanical processing will be most economical in operation at full capacity of the largest feasible shear unit or multiples thereof. The cost of units for shearing fuel assemblies is a rather inflexible function of their capacity, which for a particular type of fuel assembly is controlled mainly by the speed of loading fuel bundles and not by the shearing rate, which is quite rapid (4-6 strokes per minute). If, for example, a shear is selected which will shear only subassemblies, thereby halving the tonnage capacity, the cost is only $30 \%$ less than for a large shear.

Criticality hazards present a much greater problem in the continuous conveying and leaching equipment of the shear-leach method than in the Sulfex batch dissolvers. In continuous equipment, the possibility of concentration transients in the liquid phase due to changes in the rate of leaching of sheared and crushed fuel causes much greater concern about the probability of a nuclear excursion, and the impossibility of immediate checks on concentration increases the number of unknown factors. The unconventional shape of the equipment items also adds to the problem. A greater safety factor may therefore be needed in design to attain the same degree of reliability as the simpler sulfex cylindrical-lube batch dissolver system. 


\subsection{BASIS OF COST COMPARISON}

The cost comparison between Sulfex dejacketing-core dissolution and mechanical shear-leach head-end processes is based on assumptions outlined in the following paragraphs and in the Appendix. The fuel considered is stainless steel-jacketed uranium oxide fuel of low enrichment ( $\leq 5 \%)$ similar to the Nuclear Merchant Ship Savannah (NMSS) fuel, large amounts of which will probably need to be processed by about 1975. The assumed throughput is that of one mechanical shear of a shear-leach plant and of a Sulfex plant of the same capacity. This assumption maximizes the production rate and minimizes costs of the mechan1cal processing plant without biasing the estimate of the aqueous plant which must lave multiple batch dissolvers for a high throughput. 'Ihe stiddies are confined to the head ends and waste systems since dill other parts of the plant, such as solvent extraction, are essentially identical. Thus, the bulk of the processing equipment, buildings, etc., need not be designed, specified, and costed, and the economics of the comparison are not masked by the large capital and operating costs. for the major part of the plant.

Both plants are designed for remote maintenance through the first cycle and direct maintenance of other parts. A complete duylicatc line of shear and leachers are provided to insure continuous production despite a major equipment failure. Vlewing windows are belleved desirable and are used in both head-end processes. No attempt was made to optimize equipment design on either process. For both processes material balance flowsheets, an equipment f'lowsheet, plant head end layout, and evaluation, were prepared, heat loads, fluid flow rates, and batch sizes were calculated where necessary, and process equipment was sized. Capital and operating cost estimates were based on the estimated cost of major equipment by well known methods ${ }^{6-9}$ but including the best judgment of the authors on a number of points where little information is known or is a subject of controversy.

In comparison of waste costs, capital and operating costs for disposal of the waste from the shear-leach head end were estimated, but estimates made by others ${ }^{4,12}$ were used for sulfex waste storage costs. 
Sulfex (Fig. 1A). A material balance flowsheet (Fig. Al), equipment identification flowsheet (Fig. A2), equipment layout (Fig. A3), and a sectional elevation (Fig. A4) were prepared for the Sulfex head-end process. Factors involved in the plant design are discussed in the Appendix. The design throughput is 12 fuel assemblies per day for 300 operating days per year. At $222 \mathrm{~kg}$ of uranium per assembly, the capacity must be 2.66 metric tons/day, 799.2 metric tons/year. This production rate requires six dissolvers operating in two banks of three on a 12-hr cycle for each fuel assembly. Tank sizes, pump flow rates, and batch makeup volumes correspond.

Spent reactor fuel is brought into the plant and held in the storage canal for at least 120 days', preferably 180 days', decay. Before processing, an underwater saw removes all inert metal parts that can be safely detached. The cropped assembly is loaded into a sacrificial basket of carbon steel to facilitate charging to a dissolver by an overhead crane. Details of metal removal and loading procedure depend on the element design, but the addition of mild steel as a crane basket, steel wool, or chain aids in initiating dissolution promptly by depassivation of the stainless steel. Assemblies are transferred to the main canyon and charged to the dissolvers as required.

The stainless steel jacket is removed by dissolution in boiling $4 \underline{M}$ sulfuric acid, fed continuously over a 5-hr period, the overflow passing through a centrifuge to remove particles of $\mathrm{UO}_{2}$ and stainless steel. The clarified overflow is collected in a large tank with a geometrically safe bottom section in case $\mathrm{UO}_{2}$ inadvertently reaches this point. The dissolver is cooled and the contents are jetted through the centrifuge into the safe-bottomed hold tank. The dissolver contalning the $\mathrm{UO}_{2}$-core is thoroughly washed with water, which is centrifuged and then stored in wash hold tanks for use in making up the next batch of sulfuric acid dissolvent.

Hydrogen gas produced during dejacketing is burned with oxygen. The product, a mixture of excess oxygen and water vapor, is remixed in the main off-gas system. The dissolver system is purged with nitrogen between the sulfuric and nitric acid cycles to prevent formation of 


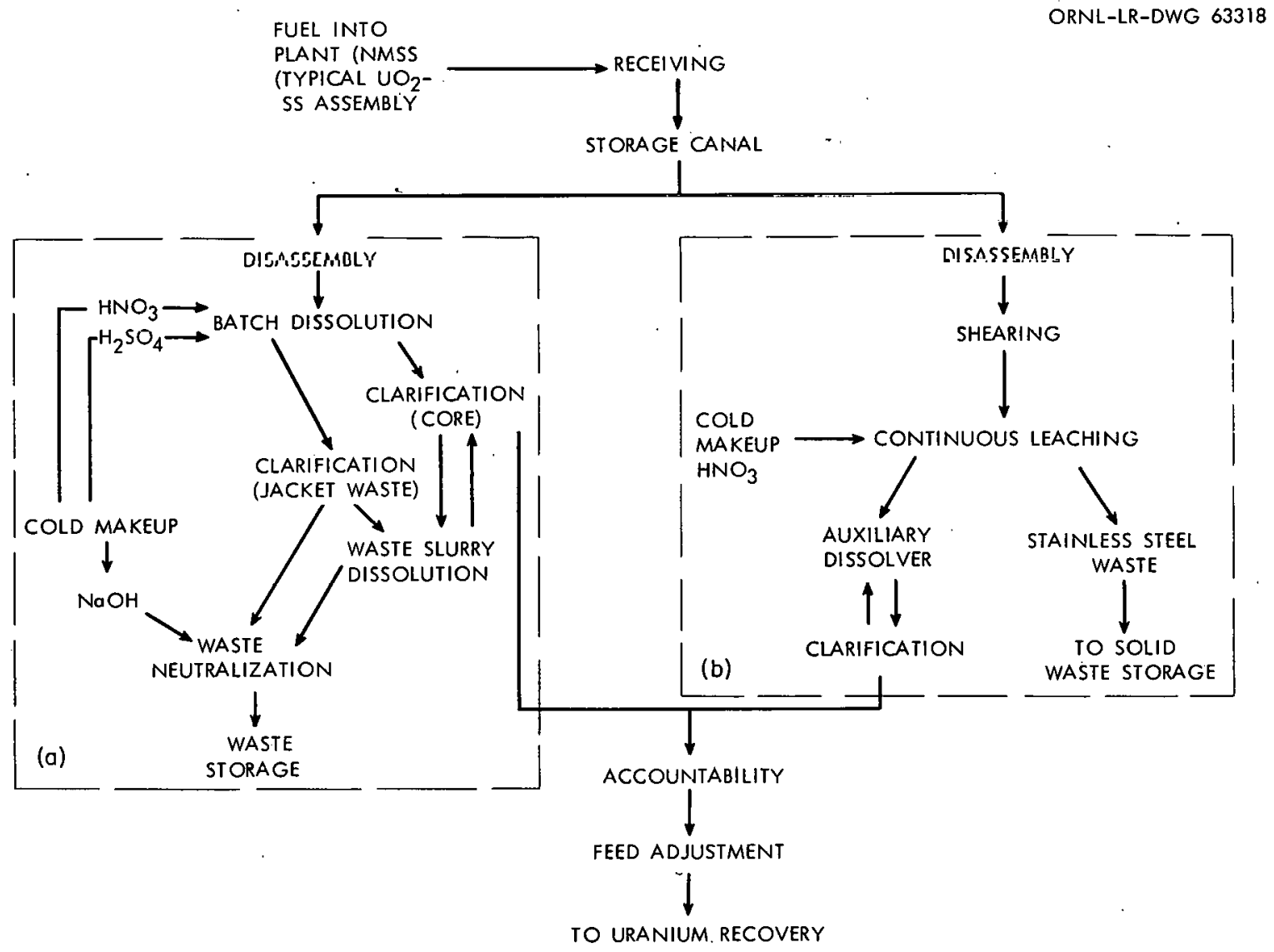

Fig. 1. Outline of (a) sulfex-core dissolution and (b) mechanical shear-leach head end processes. Only process steps within dashed lines are considered in cost comparison. 
explosive mixtures of hydrogen with air, oxygen, $\mathrm{HNO}_{3}$ vapor, or nitrogen oxides.

For core dissolution a measured batch of cold water is placed in the dissolver to moderate the initial reaction, and then boiling $10 \mathrm{M} \mathrm{HNO}_{3}$ is fed to dissolve the $\mathrm{UO}_{2}$. A total of $4 \mathrm{hr}$ is allowed for total dissolution although it may be essentially complete within $2 \mathrm{hr}$. Uranium-bearing solution is clarified by centrifugation and surged in geometrically safebottomed product tanks. The dissolver system is carefully washed to prevent passivation and soluble losses in the next decladding cycle, and the washings are added to the main product. Waste sulfuric acid is neutralized with $50 \%$ caustic solution and the resulting slurry pumped to the waste disposal tanks. The sludge in each centrifuge is thoroughly washed and jetted to the waste slurry dissolver, where extended treatment with nitric acid dissolves all fissionable material. Solids trapped in safebottomed tanks are jetted back through the centrifuge and through the waste slurry dissolver. Sludge is discarded along with the slurry of neutralized sulfuric acid when analysis shows it to be barren of values.

Shear-Leach (Fig. IB). A material balance flowsheet (Fig. A5), equipment identification flowsheet (Fig. A6), equipment layout (Fig. A7), and sectional elevations (Figs. A8-9) were prepared. A cutaway view of a typical shear-leach complex of lower capacity than the size selected in this study is shown in Fig. 2. Factors involved in the plant design are presented in the Appendix.

The plant size and design throughput determine the number and length of inclined drum rotary units to maintain production while providing the required length of holdup time $(6 \mathrm{hr})$. One fuel assembly is sheared and stored every $2 \mathrm{hr}$ to provide leacher feed for the next $2 \mathrm{hr}$; a total of 12 sheared assemblies per day for 300 operating days per year is required. Tank sizes, pump flow rates, and batch makeup volumes correspond. Spent reactor fuel is brought into the plant for at least 120 days', preferably 180 days', decay. Before processing, an underwater saw is used to remove all inert metal parts that can be safely detached. The assembly is loaded into a shear envelope, a feed chamber of the shear proper. Loaded envelopes are conveyed underwater to the main canyon and fitted to the shear 


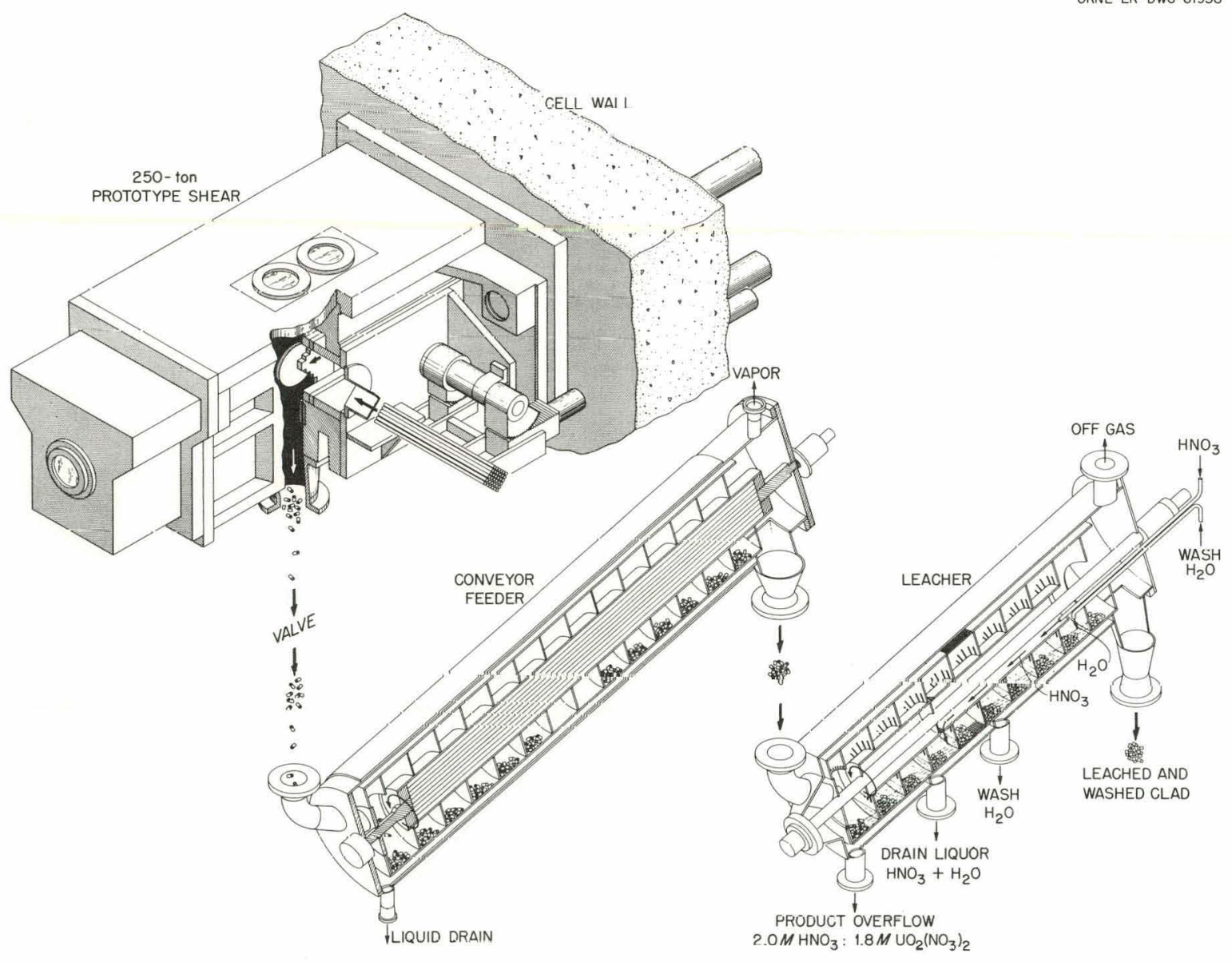

Fig. 2. Cutaway view of a typical shear-leach complex with a single leacherwasher unit. 
housing (Figs. A8-9). Shearing proceeds at about 6 cuts per minute as the fuel assembly is progressively advanced into the shear by a hydraulically driven ram. Sheared lengths of about $I$ in. are dropped into an inclined drum rotary conveyor-feeder. The entire assembly is sheared into consecutive compartments of the conveyor in 20-30 min. An interlock with the shear prevents more than a limited volume of sheared pieces from being fed to any one of the 10 flights used in the $12-f l i g h t$ conveyor. The envelope and shear housing are washed down by an internal spray system. The conveyor-feeder is one of three inclined drum rotary processing units, each containing 12 compartments (Appendix), providing for semi-continuous processing of the sheared feed. Each of the 12 compartments formed by flush welding of a continuous spiral to the inside of a cylinder holds chopped solids. The second, a leacher, and the third, a leacher-washer, rotate at $4 \mathrm{rph}$ to provide a total holdup time in each unit of $3 \mathrm{hr}$. Four batches of sheared pieces per hour are fed to consecutive flights of the leacher (unit 2), which in turn delivers four flights of leached jackets to the leacher-washer (unit 3). In turn, the leacher-washer dumps four flights per hour of leached and washed jackets to a waste receiver. In the last four flights ( $1 \mathrm{hr}$ holdup) of the leacher-washer, wash water flows countercurrently to the batches of leached jackets and is drained from the unit. In the first eight flights ( $2 \mathrm{hr}$ holdup) of the leacher-washer, hot $10 \mathrm{M} \mathrm{HNO}_{3}$ flows countercurrently to the batches of chopped fuel draining from the unit as product. In all 12 flights ( $3 \mathrm{hr}$ holdup) of the leacher, hot dilute nitric acid made by mixing the condensate return with strong acid and wash water from the leacher-washer flows countercurrently to batches of sheared fuel containing $\mathrm{UO}_{2}$ cores. Both the leacher and leacher-washer are steam-jacketed for heating, and both are connected to the main off-gas condenser. Most of the leaching of the crushed $\mathrm{UO}_{2}$ from its tubular jacket should occur in the first four stages of the leacher. The remaining eight stages in the leacher, the eight strong acid leaching stages, and four washing stages in the leacher-washer provide a large safety factor against loss of fissionable and fertile values to the waste. Provisions for re-leaching and inspection of the waste jackets were not included in the plant. The main product stream, overflowing from the leacher, is fed to an auxiliary dissolver system or digester via a settler where $\mathrm{UO}_{2}$ and stainless steel 
fines may collect. The overflowing product stream is clarified by a centrifuge. Periodically, any undissolved solids in the auxiliary dissolver are jetted to the centrifuge. These solids are washed and fed to the rotary leacher and thence to the auxiliary dissolver for re-leaching or to waste disposal. Most of the solids are expected to be stainless steel fines, which can be recharged to the rotary leacher and eventually discharged to a solids waste receiver.

Waste. The intermediate-activity Sulfex waste is produced by neutralizing the sulfuric acid solution containing dissolved stainless steel with $50 \%$ caustic (NaOH). A solution of sodium sulfate is formed in which precipitated hydroxides or basic sulfates of iron, chromium, and nickel are suspended and possibly hydrated sodium sulfate crystals if the solution is saturated at the storage temperature. Neutralized stainless steel waste slurry can be produced at $20 \mathrm{~g}$ SS/liter, which. was selected for this cost study. A $20 \mathrm{~g}$ SS/liter waste slurry results from neutralizing the dejacketing solution containing $30 \mathrm{~g}$ SS/liter with caustic. Slurries of $50 \mathrm{~g} \mathrm{SS} /$ liter up to a maximum of $80 \mathrm{~g}$ SS/liter can be made, although this should result in a thick gel undesired in storage tanks. The stainless steel loading and excess acid have considerable effect on the consistency of the slurry produced by neutralization with caustic. After. being checked for. the absence of t'issionable materials before neutralization, the slurry is pumped to tanks at a waste farm for perpetual-care storage. The relative volume of waste is 10-100 times as much from Sulfex as from mechanical shearleach. With the choice of flowsheets used in this study, a volume ratio of about 50 resulted. The amount of waste per $\mathrm{kg}$ of uranium processed also depends on the fuel assembly construction and how much excess metal can be removed before processing.

Stainless steel waste from shear-leach processing is loosely packed batches of chopped tubes leached free of $\mathrm{UO}_{2}$ and thoroughly washed with water. Chopped, leached; and washed jackets (1-in. lengths) have a bulk density of $1 \mathrm{~kg} /$ liter (86-88\% voids), which could be increased to at least $2 \mathrm{~kg} /$ liter by flattening or crushing. They are expected to be quite radioactive from activation of $\mathrm{Fe}, \mathrm{Ni}, \mathrm{Cr}, \mathrm{Mn}$, and $\mathrm{Co}$ in the metal and from small traces of fission products that diffuse into the metal. Permanent 
disposal by storage in underground steel tanks with perpetual care-taking appears practical. About three 10- by 60-ft cylindrical tanks per year would contain the waste metal at the design production rates. The plant would produce $3.6 \times 10^{5} \mathrm{~kg}$ of waste per year, requiring at least 95,000 gal of waste storage volume per year.

Washed jacketing (Fig. A9) is collected twice a shift from the washer in 55-gal stainless steel containers and carried by crane to a storage area of 24 drums capacity. Each drum passes through a decontamination room in a loading blister of the main plant, and the contents are unloaded through the floor into a top-loading lead-shielded carrier of $\sim 8 \mathrm{ft}^{3}$ volume. On the outside, lead-shielded carriers are lifted into position for loading under the floor of the loading blister by an elevator. When loaded and lowered to road level, these are picked up by a straddle carrier and transported to the waste field. The carriers and waste tankage were designed (Fig. AlO), but details of the loading blister were not. Cost estimates for the waste disposal plant are based on 20 years' operation, during which three 10-ft-dia by 60-ft-high tanks would be filled to 0.9 of their total volume each year. Meanwhile, an escrow fund is built up sufficient to provide perpetual operating costs after 20 years. New tanks are installed every year and charged as an operating cost, and all other facilities, including land, are amortized over the first 20 years. No profit is included. Because the radioactivity is well fixed and in a noncorrosive form, no tank replacement is required. After sufficient length of time part of the escrow fund and salvage value of equipment (lead, etc.) could be used to pay for filling the tanks with concrete. A hazard insurance premium of $\$ 100,000$ per year is included during the first 20 years.

\subsection{COMPARATIVE CAFITAL AND OPERATING COSTS}

The major process equipment items of the Sulfex (Table Al) and shearleach (Table A2) head end processes. were cost-estimated from a variety of sources $^{6-11}$ and adjusted to an Engineering News Record Index $(1913=100)$ of 813. Annual costs of materials and utilities (Table A3) and operating labor (Table A4) were estimated. A comparative capital cost estimate (Table 1 ) and a comparative operating cost (Table 2) were prepared. A number of guesses and approximations were Involved in both. The capital 
Tabie 1. Comperative Capital Costs of Equipmen-

\begin{tabular}{|c|c|c|c|c|}
\hline \multirow[b]{2}{*}{ Equipnent } & \multicolumn{2}{|c|}{ Sulfex } & \multicolumn{2}{|c|}{ Shear-Leach } \\
\hline & $\begin{array}{l}\text { Delivered } \\
\text { (P) }\end{array}$ & Installed & $\begin{array}{c}\text { Ielivered } \\
\text { (P) }\end{array}$ & Installed \\
\hline \multirow[t]{2}{*}{$\begin{array}{l}\text { Non-Radioactive Equipment } \\
\text { Radioactive Equipment }\end{array}$} & $\begin{array}{l}193,969 \\
839,989 \\
\end{array}$ & $\begin{array}{r}252,160 \\
1,091,986 \\
\end{array}$ & $\begin{array}{r}45,250 \\
766,222 \\
\end{array}$ & $\begin{array}{r}58,825 \\
996,089 \\
\end{array}$ \\
\hline & $1,033,958$ & $1,344,146$ & 311,472 & $1,054,914$ \\
\hline \multirow[t]{2}{*}{$\begin{array}{l}\text { Spare Equipment (not instailed) } \\
\text { Piping }(2.5 \times \mathrm{P}) \\
\text { Instrumentation }(1.0 \times \mathrm{P}) \\
\text { Electrical }(0.1 \times \mathrm{P})\end{array}$} & & $\begin{array}{r}223,110 \\
2,584,895 \\
1,033,958 \\
\quad 103,396 \\
\end{array}$ & & $\begin{array}{r}103,600 \\
2,028,680 \\
811,472 \\
81,147 \\
\end{array}$ \\
\hline & & $5,289,505$ & & $4,079,813$ \\
\hline \multirow[t]{2}{*}{$\begin{array}{l}\text { 'Norking capital } \\
30 \text { days' supply of raw neterials }\end{array}$} & & 83,800 & & 16,340 \\
\hline & & $5,373,305$ & & $4,096,153$ \\
\hline
\end{tabular}

* Amortization of capital investment is based on grand totals less the working capital cosi of a 30 day inventory of process chemicals. 
Table 2. Comparative Annual Operating Costs

\begin{tabular}{|c|c|c|c|c|}
\hline \multirow[b]{2}{*}{ Item } & \multicolumn{2}{|c|}{ Sulfex } & \multicolumn{2}{|c|}{ Shear-Leach } \\
\hline & $\$ / \mathrm{kg} \mathrm{U}$ & $\$ /$ year & $\$ / \mathrm{kg} \mathrm{U}$ & $\$ /$ year \\
\hline $\begin{array}{l}\text { Raw materials } \\
\text { Operating labor (A) } \\
\text { Labor supervision (B) ( } 20 \% \text { of A) } \\
\text { Maintenance ( } 10 \% \text { of fixed capital) } \\
\text { Operating supplies } \\
\text { Utilities }\end{array}$ & $\begin{array}{l}1.256 \\
0.436 \\
0.087 \\
0.634 \\
0.063 \\
0.012 \\
\end{array}$ & $\begin{array}{r}1,004,048 \\
349,000 \\
69,800 \\
506,640 \\
50,664 \\
9,200 \\
\end{array}$ & $\begin{array}{l}0.245 \\
0.280 \\
0.056 \\
0.497 \\
0.050 \\
0.008 \\
\end{array}$ & $\begin{array}{r}195,978 \\
224,000 \\
44,800 \\
397,621 \\
39,762 \\
6,300 \\
\end{array}$ \\
\hline Utilities & 2.488 & $1,989,352$ & 1.136 & 908,461 \\
\hline \multirow[t]{2}{*}{$\begin{array}{l}\text { Payroll overhead }(20 \% \text { of } A+B) \\
\text { Plant overhead }(50 \% \text { of } A)\end{array}$} & $\begin{array}{l}0.104 \\
0.218 \\
\end{array}$ & $\begin{array}{r}83,600 \\
174,500 \\
\end{array}$ & $\begin{array}{l}0.067 \\
0.140 \\
\end{array}$ & $\begin{array}{r}53,760 \\
112,000 \\
\end{array}$ \\
\hline & 0.322 & 258,100 & 0.207 & 165,760 \\
\hline Amortization ( $15 \%$ per year) & 0.966 & 772,529 & 0.776 & 620,942 \\
\hline Grand Totals & 3.78 & $3,019,981$ & 2.12 & $1,695,163$ \\
\hline
\end{tabular}


cost for the Sulfex head end plant and equipment without the building was $\$ 5,373,305$ and the annual operating cost was $\$ 2,247,452$ without amortization and \$3,019,981 with amortization of fixed capital over 6-2/3 years. Profit was not included in the calculation. Per unit of throughput, the operating costs were. $\$ 1.27$ per pound (\$2.81 per kilogram) of uranium without amortization and $\$ 1.71$ per pound ( $\$ 3.78$ per kilogram) of uranium with amortization over 6-2/3 years. The total cost of head end processing including amortization and waste was $\$ 15.78$ per kilogram of uranium.

The capital cost of the shear-leach head end plant and equipment without the building was $\$ 4,096,153$ and annual operating cost $\$ 1,074,161$ without amortization and $\$ 1,695,163$ with amortization of fixed capital over $6-2 / 3$ years. Profit was not included in the calculation. Per unit of throughput, the operating costs were $\$ 0.61$ per pound ( $\$ 1.35$ per kilogram) of uranium without amortization and $\$ 0.96$ per pound ( $\$ 2.12$ per kilogram) with amortization of $6-2 / 3$ years. The total cost of head end processing including amortization and waste was $\$ 2.71$ per kilogram of uranium.

Waste. The chief reasons for the large difference in waste cost between the two processes are the much larger volume of Sulfex waste to be stored and the assumption that tanks for storage of solid metal need not be replaced while those that store liquid waste will require replacement approximately every 50 years.

The cost of handling Sulfex waste in 5,000,000-gal concrete-lined steel tanks was developed from a study by Stockdale, Arnold, and Blomeke 4 on the general problem of tank disposal of aqueous wastes. They considered that one tank would always be available as a standby in case of corrosion and that, because of corrosion, each tank would be replaced at 50-year intervals in perpetuity. A sinking fund, treated as an operating cost, is set up during the operating life of the associated processing plant to provide a perpetual annuity, the proceeds of which would be sufficient to provide the required operating funds. The minimum cost as an operating charge for this operation was estimated as $\sim \$ 2$ per gallon for very large waste storage facilities and somewhat higher (\$3-\$4 per gallon) for smaller scale facilities. This report used an estimated cost of $\$ 2$ per gallon. At the design rate of 4.78 million gal/year ( $\sim$ tank per year required), this amounts to an annual operating charge of $\$ 9.56$ million per year. 
It is apparent that considerable reduction of processing costs would result from an increase in stainless steel concentration in the waste which was selected at $30 \mathrm{~g}$ stainless steel/liter prior to neutralization. Concentration by evaporation of acidic or neutralized waste is quite difficult, requiring more cell space and recycle of water. A change in dissolvent composition to 5 or $6 \mathrm{M} \mathrm{H}_{2} \mathrm{SO}_{4}$ would change the time cycle and require more dissolver units and cell space and increase the problems of corrosion and sludge and possibly increase soluble uranium losses.

Estimates of the shear-leach capital cost (Table 3); operating cost during the first 20 years (Table 4), and operating cost after 20 years (Table 5) were prepared for comparison with the cost of aqueous waste storage required for the Sulfex head-end process. At a processing rate of 2.664 metric tons of uranium per operating day (300-day year), including perpetual care, the waste disposal cost is $\$ 0.27$ per pound of uranium, $\$ 0.60$ per pound of stainless steel, or $\$ 4.98$ per gallon of stainless steel waste.

The total annual operating cost was estimated as $\$ 473,010$ per year, including an annual payment into an escrow fund to ensure perpetual operating costs after a 20-year filling period. Waste costs could be lower since a considerably larger volume of waste could be handled in the same facilities with major added costs only for additional tanks. Sufficient land is available, and caretaking costs would increase only slightly with an increased number of tanks. Crushing of stainless steel jackets, already quite dense compared to aqueous wastes but only at $15 \%$ solids by volume, to a higher bulk density would result in further savings. 
Table 3. Shear-Leach Waste Processing Capital Cost

Item

Cost

Land, 100 acres at $\$ 400 /$ acre

Site development, grading, draining, layout; $\$ 100 /$ acre

$\$ 40,000$

10,000

Fence, $5280 \mathrm{ft}$ at $\$ 5.20 / \mathrm{ft}$

27,500

Road to waste site, $1 / 2$ mile at $\$ 5 / \mathrm{ft}$

Building at waste site; $450 \mathrm{ft}^{2}$ at $\$ 10 / \mathrm{ft}^{2}$

Loading port (blister) at main processing building,

13,200

4,500

1 decontamination cell with small viewing window,

120,000

remote crane ( 1 ton), 2 discharge hoppers, valves, chutes, carrier elevators

Lead-shielded carriers (2), $8 \mathrm{ft}^{\overline{3}}$ ss liner, 6 in. ball valve, $b$ in. Lead ( $b$ yr life)

Straddle carrier (truck)(2), 10 ton (10 yr life)

Waste cans inside plant (24) ( 1 yr life)

10,600

24,000

Total

3,600

$\$ 253,400$

Table 4. Shear-Leach Waste Annual Operating Cost During 20 Year Filling Life

Item

Cost

3 storage tanks, carbon steel, $10 \mathrm{ft}$ dia $\times 60 \mathrm{ft}$ long, buried 5 ft deep, each complete with ' 74 t't of' concrete road at ground level; twèlve 8 -in. loading pipes, 12 sliding lead doors, li 55 cover plates, vent filter, lights, instrumentation, cathodic protection, completely installed

24 waste cans inside plant

Operating labor (A), $3 \mathrm{men} / \mathrm{shift} \times 4=12$ employees,

3,600

74,900

Supervision (B) ( $10 \%$ of $A$ ) $12 \times \$ 3 / \mathrm{hr} \times 2080 \mathrm{hr} / \mathrm{yr}$

Maintenance (C)

Plant supplies ( $10 \%$ of $\mathrm{C}$ )

Utilities

Payroll overhead ( $22 \%$ of $A+B$ )

Plant overhead ( $63 \%$ of $A$ )

Amortization (average over $20 \mathrm{yr}$ )

Property tax ( $1 \%$ of fixed capital including an average of 30 tanks in the ground)

Hazard insurance

$\$ 98,400$

Annual payment to produce escrow fund of $\$ 2,250,000$ after

20 years at $4 \%$, in turn yielding $\$ 90,000 / y r$ in perpetuity for caretaking costs

7,490

15,845

1,584 .

3,125

16,478

47,450

15,300

12,338

100,000

76,500 
Table 5. Shear-Leach Annual Operating Costs After 20 Years of Caretaking

Item

Cost

Operating labor (A), $1 \mathrm{man} / \mathrm{shift} \times 4=4$ employees, $4 \times \$ 3 / \mathrm{hr} \times 2080 \mathrm{hr} / \mathrm{yr}$

Supervision (B) ( $10 \%$ of A)

Maintenance (C)

Plant supplies ( $10 \%$ of $\mathrm{C}$ )

Utilities

Payroll overhead (20\% of $A+B$ )

Plant overhead ( $50 \%$ of A)

Property tax

Hazard insurance

\author{
2,500 \\ 4,260 \\ 426 \\ 2,000 \\ 5,500 \\ 12,500 \\ 20,600 \\ 10,000 \\ Total \\ $\$ 82,786$ \\ plus $\sim 9 \%$ contingency $=\$ 90,000 / \mathrm{yr}$
}

\title{
5.0 REFERENCES
}

1. "Chemical Processing of Irradiated Fuels from Power, Test and Research Reactors," Proc. AEC Symposium, Richland, Wash., Oct. 20-21, 1959, TID-7583.

2. B. C. Finney and B. A. Hannaford, "Sulfex Process: Engineering Scale

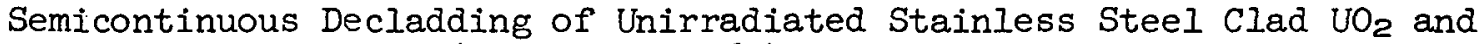
$\mathrm{UO}_{2}-\mathrm{ThO}_{2}$," ORNL-3072 (March 21, 1961).

3. L. M. Ferris and A. H. Kibbey; "Laboratory Development of the Sulfex Process for the Dissolution of Consolidated Edison Power Reactor Fuel," ORNL-2174 (Oct. 16, 1959). 
4. W. G. Stockdale, E. D. Arnold, and J. O. Blomeke, "The Economics of Permanent Disposal of Power Reactor Wastes in Tanks," ORNL-2873 (in (press).

5. W. G. Stockdale, ORNL, conversation Nov. 9, $196 \mathbf{I}^{\circ}$.

6. R. S. Aries and R. D. Newton, "Chemical Engineering Cost Estimation," McGraw-Hill Book Co., Inc., New York (1955).

7. M. S. Peters, "Plant Design and Economics for Chemical Engineers," McGraw-Hill Book Co., Inc., New York (1958).

8. 0. T. Zimmerman and I. Lavine, "Chemical Engineering Costs," Industrial Research Service, Dover, New Hampshire (1950).

9. F. C. Vilbrandt and C. E. Dryden, "Chemical Engineering Plant Design," MeGr"aw-Hlll Buuk Cu., Iilc., PNew Yüh (1959).

10. C. H. Chilton, editor, "Cost Engineering in the Process Industries," McGraw-Hill Book Co., Inc. New York (1960).

il. Gibson Morris (ORNL Engineering Dept.), letter to B. F. Bottenfield (ORNL Chemical Technology Division), "Power Reactor Fuel Reprocessing Darex and Sulfex Processes vs. Darex-Sulfex Process," July 8, 1959.

12. "Chemical Technology Division. Annual Progress Report for Period Ending August 21, 1960," ORNL-2993, p. 96.

13. B. C. Finney, unclassified Notebook No. A-1591, July 15, 1960.

14. A. R. Irvine, J. M. Holmes, A. C. Schafer, and J. P. Nichols, "A Review of Factors Bearing on the Nuclear Safety of Equipment for the PRFR Head End Facility," ORNL CF 60-1-102 (Jan. 13, 1960).

15. J. P. Nichols, "Proposed Methods for Maintaining Nuclear Safety in the Darex-Sulfex Head-End Process," ORNL CF 59-10-40 (Oct. 15, 1959).

16. AMF Atomics "Mechanical Disassembly of Spent Power Reactor Fuels Feasibility Report," for period Feb. 18 to Sept. 18, 1957, AMF-GR-24-57, p. 94 . 


\subsection{APPENDIX}

\subsection{Stoichiometry of Chemical Flowsheets}

The material balance flowsheets were based on the considerations that:

1. $\mathrm{UO}_{2}$ dissolves in nitric acid by

$$
\begin{gathered}
\mathrm{UO}_{2}+4 \mathrm{HNO}_{3} \rightarrow \mathrm{UO}_{2}\left(\mathrm{NO}_{3}\right)_{2}+2 \mathrm{NO}_{2}+2 \mathrm{H}_{2} \mathrm{O} \\
\mathrm{UO}_{2}+8 / 3 \mathrm{HNO}_{3} \rightarrow \mathrm{UO}_{2}\left(\mathrm{NO}_{3}\right)_{2}+2 / 3 \mathrm{NO}+4 / 3 \mathrm{H}_{2} \mathrm{O}
\end{gathered}
$$

These equations present an over-similified picture, since $\mathrm{UO}_{2}$ dissolves by a variety of mechanisms depending on the acid concentration and producing at least one other gaseous product, $\mathrm{N}_{2} \mathrm{O}$, and probably others. However, their use allows an estimate of the off-gas volume and heat release associated with the process.

2. Oxidation and recovery of nitrogen oxides takes place by

$$
\begin{gathered}
6 \mathrm{NO}+3 \mathrm{O}_{2} \rightarrow 6 \mathrm{NO}_{2} \\
6 \mathrm{NO}_{2} \rightleftharpoons 3 \mathrm{~N}_{2} \mathrm{O}_{4} \\
3 \mathrm{~N}_{2} \mathrm{O}_{4}+3 \mathrm{H}_{2} \mathrm{O} \rightarrow 3 \mathrm{HNO}_{3}+3 \mathrm{HNO}_{2} \\
3 \mathrm{HNO}_{2} \rightarrow \mathrm{HNO}_{3}+2 \mathrm{NO}+\mathrm{H}_{2} \mathrm{O}
\end{gathered}
$$

The continued production of NO by this process prevents complete recovery except with a more extensive absorption system and with the use of oxygen rather than air for oxidation. The overall recovery of nitrogen oxides in the condenser system was taken as $66.7 \%$.

3. Discolution of stainless steel 1s represented by the general equation

$$
\mathrm{SS}+\mathrm{H}_{2} \mathrm{SO}_{4} \rightarrow(\mathrm{SS}) \mathrm{SO}_{4}+\mathrm{H}_{2} \uparrow
$$

The molecular weight of stainless steel was taken as $55 ; 1.1$ mole of hydrogen is produced per mole of stainless steel as measured experimentally. ${ }^{2}$ The amount of $50 \%$ caustic required for neutralization was estimated from the excess added over that required to react with the stainless steel dissolved.

The Sulfex chemical flowsheet was based on results of development work at ORNL. ${ }^{2,3}$ It was estimated that $5 \mathrm{hr}$ in boiling $4 \underline{\mathrm{M}} \mathrm{H}_{2} \mathrm{SO}_{4}$ would 
dissolve all but the thickest stainless steel parts. There is adequate depth in the dissolver to carry a heel of stainless steel fragments, and a heel cleanout run would be scheduled periodically. The dissolver is operated so-called "semi-continuously," 2 by adding fuel elements in batches and feeding boiling $4 \mathrm{M} \mathrm{H}_{2} \mathrm{SO}_{4}$ acid continuously during the 5-hr decladding and allowing it to overflow. This is the only feasible method of contacting a large volume of acid with a fuel element in the restricted geometry needed for criticality control. The use of $4 \mathrm{M}$ acid rather than 5 or $6 \underline{\mathrm{M}}$ results in less corrosion, at equimolar flow rates dissolution is faster, and the amount of excess acid is less (at equal fraction dissolved).* A fluffy black colloidal solid formed with acid strengths $>4 \underline{M}$ is difficult to remove completely even in a centrifuge but also has a tendency to build up and clog transfer lines and other points in equipment where turbulence is low. The use of the fastest acting dissolvent also decreases the number of dissolvers required to process the desired number of fuel assemblies per day.

The nitric acid shear-leach flowsheet was selected to produce a product stream for uranium recovery identical with that from nitric acid core dissolution of $\mathrm{UO}_{2}$ in the Sulfex head end. Leaching of crushed $\mathrm{UO}_{2}$ from 1-in. sheared lengths of stainless steel tubing is more rapid than dissolution of nonjacketed whole pellets, and the countercurrent action of the inclined drum rotary leachers is efflclent in maintaining a high dissolution rate.

Dissolution of $\mathrm{UO}_{2}$ proceeds quite rapidly in boiling nitric ac1d, with most of the $\mathrm{UO}_{2}$ dissolving during the first $2 \mathrm{hr}$, but up to $4 \mathrm{hr}$ allowed to ensure completion. A possibly violent initial reaction between $\mathrm{HNO}_{3}$ and $\mathrm{UO}_{2}$ fines is tempered by covering the $\mathrm{UO}_{2}$ in the leacher with cold water before feeding the boiling nitric acid.

* Since the loading is lower due to the higher volume rate of flow required to produce equimolar flow rates with $4 \mathrm{M}$ acid. 


\subsection{Criticality}

Criticality is a major problem in design of large-scale processing plants for spent power reactor fuels. ${ }^{14,15}$ The stainless steel-clad $\mathrm{UO}_{2}$ civilian power reactor fuels are of low enrichment ( $1.5-5 \%)$, but as processing plant capacity is increased and volumes are increased, vessel size increases and absolute criticality control can no longer be effected entirely by geometry and batch size. A combination of batch size, concentration control, vessel geometry, soluble and fixed poisons with fixed moderator, and other administrative procedures is necessary. The particular combination of features necessary and desirable depends to a high degree on the enrichment of the fuel handled. The presence of heterogeneous mixtures of $\mathrm{UO}_{2}$ pellets and of fines in uranyl nitrate solutions complicates the problem.

The designs used in the present study are believed to be at least borderline safe by present knowledge under the restrictions and limitations considered but have not been checked in detail. It is considered impractical to design large-capacity plants based on geometry control alone, and future plants will probably use every possible means of criticality control so as to reduce processing costs while maintaining safe high-capacity operation.

In the Sulfex head end dissolvers, criticality control is by batch size, geometry, and soluble poisons. Considering the NMSS element as a single unit, a 9- to 10-in. square or 12-to 13-in.-dia round pipe would suffice to receive the element physically. In two halves, one stacked on the other, only slightly smaller dimensions are allowable. A 9-in. square is considered safe with batch control and soluble poisons. Extension to larger dissolvers may be possible with further tests on full-sized units. In any case, as an additional safety factor, boric acid is used as a soluble poison in the sulfuric acid stream and cadmium nitrate in the nitric acid stream, both at limits well removed from possible saturation. The centrifuges are safe by geometry. The waste hold tanks and wash water hold tanks have safe-geometry bottoms for collection of any $\mathrm{UO}_{2}$ fines that escape the settler and centrifuge due to upsets in operation. 
In the mechanical head end, the shear is geometrically safe due to careful design of the unit. The inclined drum rotary conveyor feeder incorporates a number of features for criticality control. It usually operates dry, but under certain circumstances could be flooded with water. Carrying $252 \mathrm{~kg}$ of $\mathrm{UO}_{2}$ ( $5 \%$ enriched) divided into eight compartments ( 1.58 $\mathrm{kg}$ of $\mathrm{U}^{235}$ in. each), the unit is metal, covered outside with stainless steel-sheathed cadmium; the interior of the 8-in. central pipe is filled with polyethylene, which is clad in polyethylene-sheathed cadmium as a moderator. The shape of the $\mathrm{UO}_{2}$ as carried in the feeder approximates a truncated cylinder with stainless steel spacers every $\delta$ in. In addition, the unit is batch controlled to contain no more than one chopped assembly at a time, i.e., it is completely emptied before being loaded with the next assembly. For smaller, lower enrichment elements other than the NMSS type, the severity of the problem is greatly reduced since the total weight of $U-235$ in a batch decreases rapidly with a decrease in assembly size and enrichment of uranium. The inclined-drum rotary leacher unit is controlled by the holdup of $\mathrm{UO}_{2}$, being limited to the first two or three flights because of rapid dissolution, the size and shape of the unit, addition of limited batches from the feeder, and the additional acid of soluble cadmium as a poison in the dissolvent. This places a special emphasis on positive control: of dissolvent composition and flow rate. Other equipment in the system (auxiliary dissolver and centrifuge) is known-safe by geometry.

\subsection{Losses and Potential Cost}

Loss of fissionable values in fuel processing could become a serious cost factor. For the purpose of this study, 100\% recovery was assumed and no charge made for losses. The head end systems were designed in a manner believed to provide a high probability that losses would be slight. The cost of a processing loss is a function of the enrichment. A loss of significant cost with $5 \%$ enriched material may become insignificant with $1.5 \%$ material. Therefore statements of loss limits without specification of enrichment do not clearly define the economic picture.

There are factors in both head end processes that cause losses, but the relative magnitudes could not be estimated accurately for lack of information. During sulfuric acid decladding, the $\mathrm{UO}_{2}$ core is exposed 
for some length of time and a small soluble loss may occur. A small amount in a large volume of waste does not justify recovery. At some value of loss, however, recovery equipment would be warranted. The soluble loss is probably a function of time of contact of $\mathrm{UO}_{2}$ with the sulfuric acid, which provides a compelling reason for dissolving each $\mathrm{UO}_{2}$ charge completely.

In the shear-leach head end, no information on losses is available. The main possibility of loss is as undissolved $\mathrm{UO}_{2}$ with the waste cladding, and in this study no provision for analysis or inspection was made. An extended leaching and washing time should solve this problem if it is a factor, of course at additional cost.

In both processes $\mathrm{UO}_{2}$ fines that overflow with the product are collected in settlers and centrifuges and reworked.

\subsection{Schedule of Dissolver Operation for Sulfex Head End Process}

Dissolver operation was scheduled to utilize the minimum number of dissolvers to the maximum possible extent consistent with the estimated cycle time for dejacketing and core dissolution of a fuel element. The cycle time was estimated to be $12 \mathrm{hr}$, of which $7 \mathrm{hr}$ is dejacketing and $5 \mathrm{hr}$ is core dissolution. To process 12 assemblies per 24-hr day, a system consisting of six dissolvers operating in two parallel banks of three was chosen. The operation of the dissolvers during a 24-hr period, where $\mathrm{D}$ indicates decladding and $\mathrm{C}$ core dissolution, was:

Bank I DDDDDDD CCCCC DDDDDDD CCCCC

Bank 2 CCCCC DDDDDDD CCCCC DDDDDDD

This choice evens out the off-gas flow rate to some extent and allows a smaller off-gas system. If one dissolver becomes inoperable, only 1/6th of the plant capacity is lost until it can be replaced. The volume of nitrogen purge gas used between sulfuric acid cycles will be decreased somewhat by manifolding rather than providing for separate off-gas lines and hydrogen disposal systems for each of six dissolvers. 


\subsection{Hydrogen Evolution in Sulfex Head End Process}

Hydrogen gas is produced by dissolution of stainless steel in sulfuric acid. To equalize the comparison, costs to cover its disposal were estimated by assuming the hydrogen to be burned with oxygen, as produced, in a special burner, the water condensed, and the remaining gas stream added to the main nitrogen off-gas stream. It was assumed that one of two units operated on-line and one was a spare. Operating costs associated with hydrogen disposal include those of hydrogen to maintain pilot lights, oxygen for combustion, and nitrogen for purge of every dissolver between sulfuric and nitric acid cycles to prevent the possibility of an explosion. This is not necessarily the best method for hydrogen disposal, but its use allows assignment of a cost to the process step and returns the gas to the main off-gas stream without an appreciable volume increase.

\subsection{Rare Gas Handling}

Rare gas handling and recovery were not considered as a cost factor in this study. The recovery systems (RAGS), if required, would be essentially identical for both processes. In calculating the material balance, however, air was used as a source of oxygen for oxldation of the nitrogen oxides to estimate maximum flow rates through the equipment. If a RAGS system was attached to the flowsheet, it would be advisable to use oxygen rather than air in order to decrease the volume of inerts and thus the capital and operating costs of the system. The amount of air inleakage into a system using oxygen is critical, but difficult to evaluate other than by experimental means.

The hydrogen produced in the Sulfex head end step will contain some rare gases. With a RAGS system, this must be recovered by re-introducing the stream from the hydrogen disposal system into the main off-gas. The volume is small relative to the main off-gas when air is used for oxidation but could be appreciable if oxygen is used for oxldation. The small nitrogen purge stream for the dissolvers between the sulfuric and nitric acid cycles, is another known source of inert diluent. In a shear-leach system using oxygen for oxidation, there are two sources of air inleakage of unknown magnitude: the shear feed envelope must be removed periodically 
and the valve for removing leached stainless steel cladding for waste disposal must be opened regularly.

\subsection{Building Costs}

The overall use of floor space in the canyon for the two processes balanced out evenly and was therefore excluded as a factor in the cost estimate. The same number of viewing windows and the wall thicknesses are the same, and connected canal storage facilities are identical. The mechanical process has less canyon depth over much of its length, but the possible reduction in cost was considered slight. The sulfex step actually required more floor space for installation of equipment, but this was balanced against additional canyon floor space required for storage of waste cans. The overall result was to produce no net charge against either process for building costs, which were therefore eliminated from the cost estimate.

\subsection{Maintenance}

In a plant of this size and type, remote maintenance is practiced through the first cycle of solvent extraction. Therefore, both head end steps have remote maintenance facilities, including two cranes and a canal. Adequate spare equipment is supplied where necessary to maintain operation. Groups of equipment items are unitized into single structural frames, where possible, for rapid replacement. Equipment is interconnected by single and multiple remote connectors (jumpers). The cost of jumper provisions for the two processes were made by estimating the number and cost of connectors and the cost of unitizing equipment. In considering floor space in the canyon, sufflcient aisle and working space was left for equipment removal. For the mechanical head end process, however, a complete duplicate line of shear and three inclined-drum rotary units were required because individual replacement of equipment rapidly seemed impractical and would require a production shutdown. For the Sulfex, one unitized dissolver unit was provided as a spare for six operating units.

\subsection{Special Mechanical Equipment}

Two types of mechanical processing equipment unique in fuel processing work were used in the mechanical head end. Some features of these are 
shown in this section by way of explanation.

Mechanical Shear. A mechanical shear capable of shearing complete assemblies of tubular fuels into discrete short lengths (0.5 - 2 in.) (Fig. All) has been under development at ORNL. ${ }^{l}$ A test model (Fig. Al2) capable of shearing at least a 7 - by 7 -in. bundle of tubes and of producing a thrust of 250 tons of force was built by the Birdsboro Corporation and is being tested. A fuel assembly is inserted into the feed envelope by the loading cylinder and sealed with another (Fig. Al2) which also contains the device (Fig. Al3) to continue feeding the element as shearing proceeds. Shearing is accomplisked by a stepped blade mounted on a traveling blade holder (Fig. Al4) working against a fixed V blade. The blade holder is connected to a ram operated horlzontully turough tho osd wall. Bullu blades can be replaced remotely. The blade holder rides on adjustable gib-bearing surfaces and comes out on a rack for maintenance when the swinging door at the end of the housing (Fig. Al5) is opened. The feed envelope and cover plate are removable (Fig. Al6), showing the gag, a device to hold the element firmly during shearing. The unit is completely sealed but has two windows to allow viewing the interior by TV during operation. Internal cleaning is provided fur by a syotcm of spray nn7.7.7es. Materials of construction are consistent with the proposed use of water and hot dilute nitric acid för cleaniny.

Inclined Drum Rotary Processing Units. The inclined-drum rotary leach-

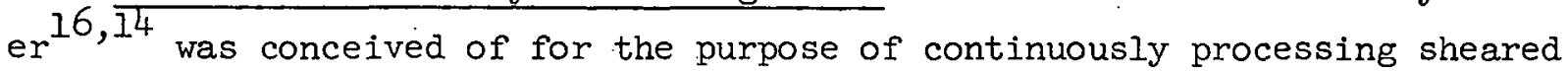
feed in a completely closed system without the disadvantages of batch dissolvers where a leach basket containing pieces of sheared cladding would have to be withdrawn after every dissulution. One leacher unit (Fig. Al7) has been built for test work and another of slightly different design for use as a feeder and conveyor. See Fig. 2, Sect. 3.0, for a cutaway view of conveyor-feeder and leacher-washer units. The unit operated satisfactorily with batches of 0.5-in.-dia by l-in. long pieces of stainless steel rod. Solids are conveyed by rotating the inner drum, and leach acid or wash water can be flowed over them countercurrently. The outer shell provides containment. It is provided with appropriate solids feed and discharge ports, liquid feed and drain lines, and an off-gas connection 
as required for the particular operation. This particular model is fitted for both leaching and washing in the same unit. 
BASIS: $\left.\begin{array}{c}\text { NMSR ELOMENT } \\ 252 \mathrm{~kg} \text { YOOZ } \\ 100 \mathrm{~kg} \\ \text { SS }\end{array}\right\}$ EAMCH

Sulfuric Acid Decladding (T hr period)
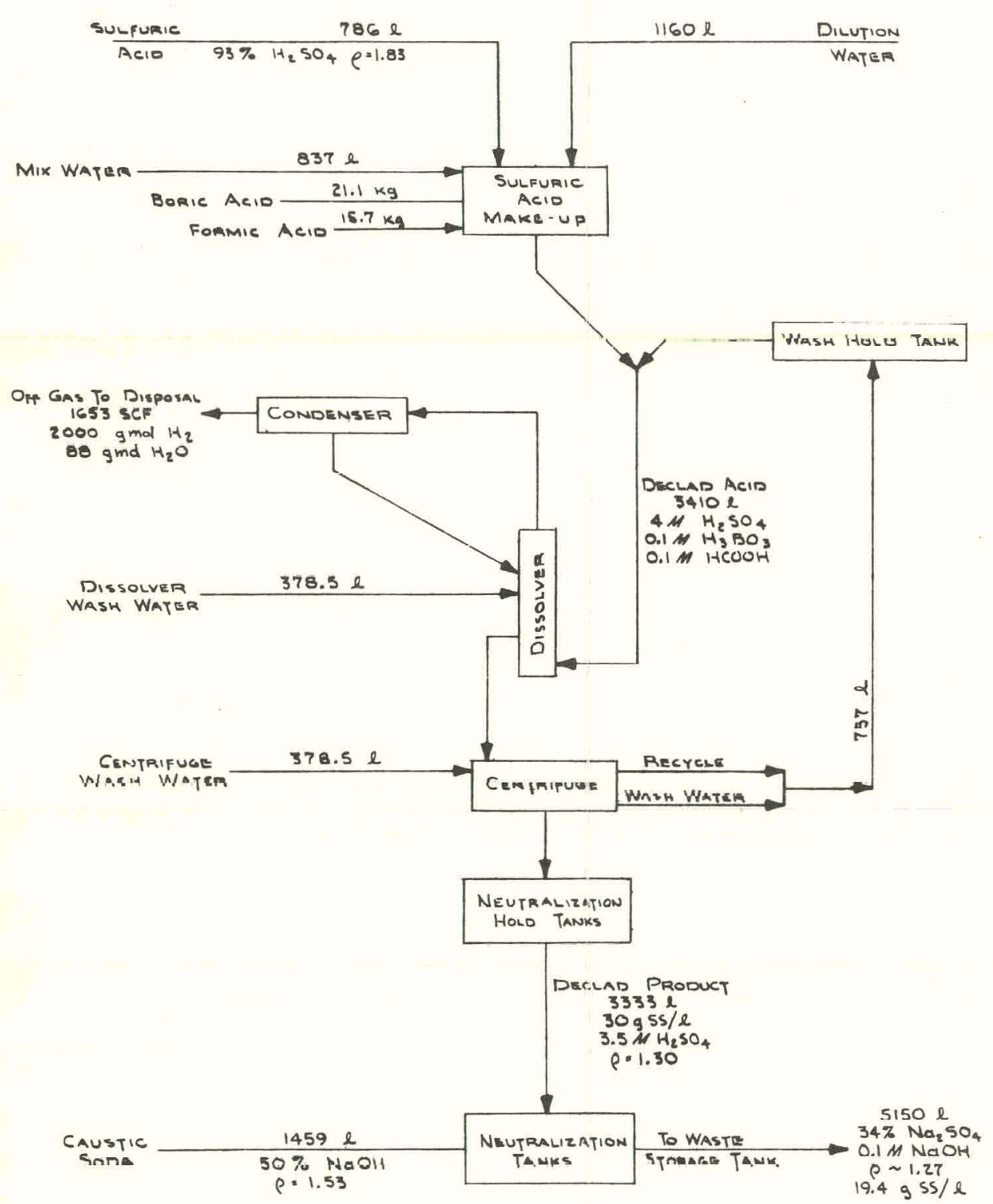

NitRic Acid CORE Dissolution ( 5 HR period)

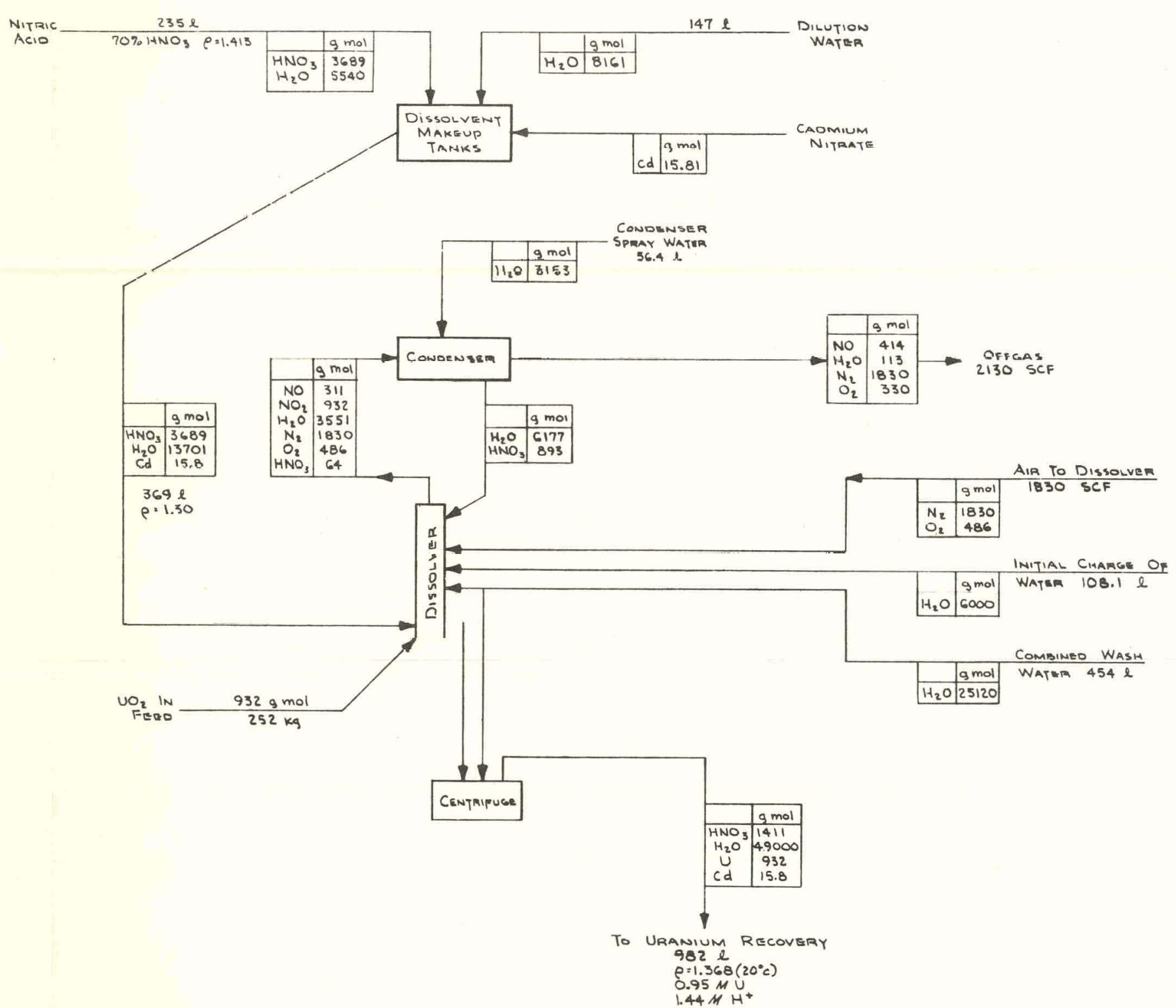

Notas:

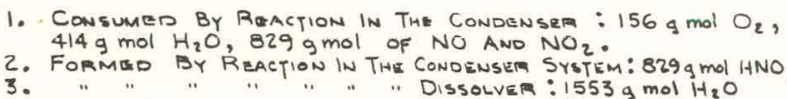

Fig. A.1. Sulfex chemical head-end process: material balance flowsheet. 


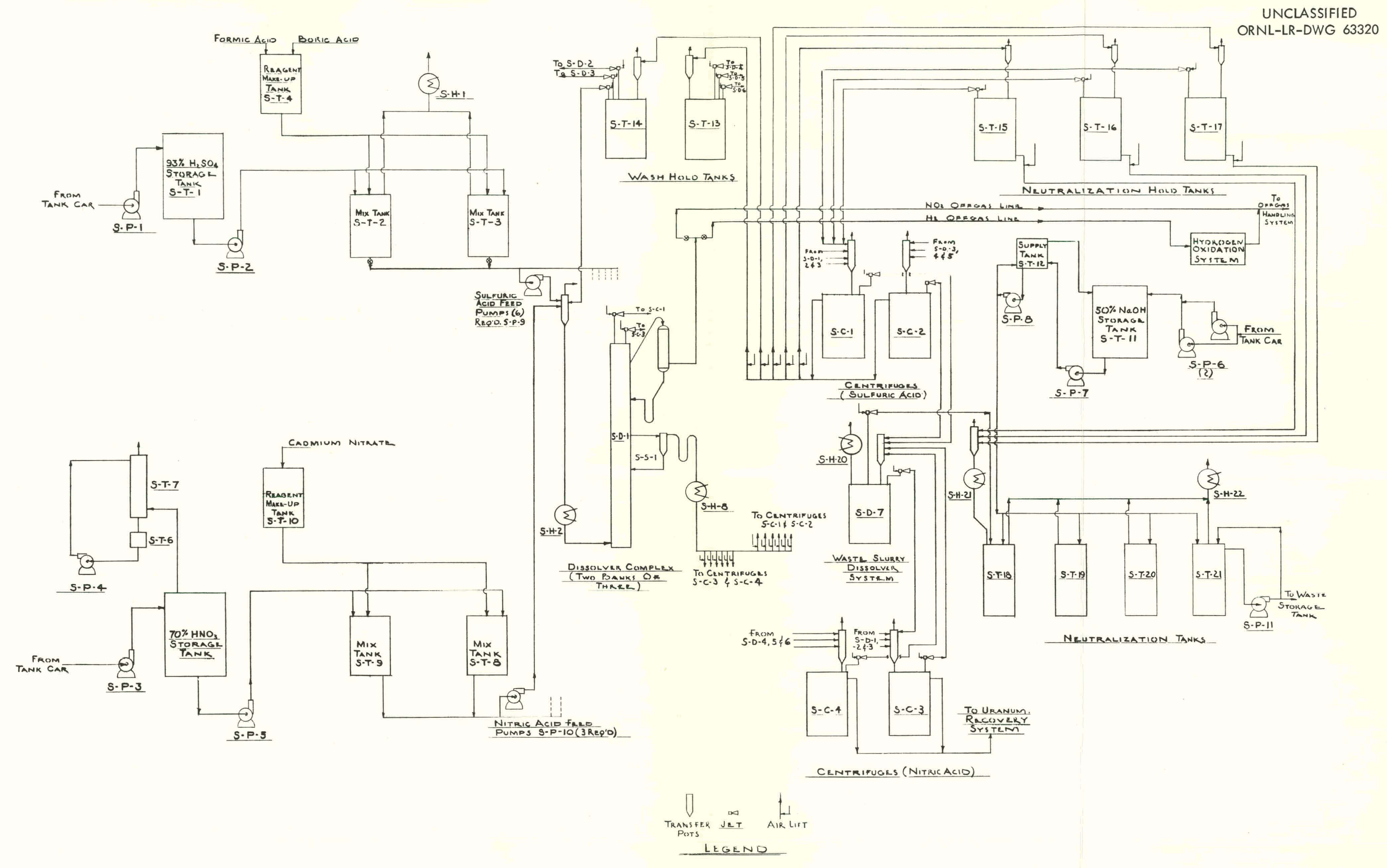

Fig. A.2. Sulfex chemical head-end process: equipment flowsheet. 


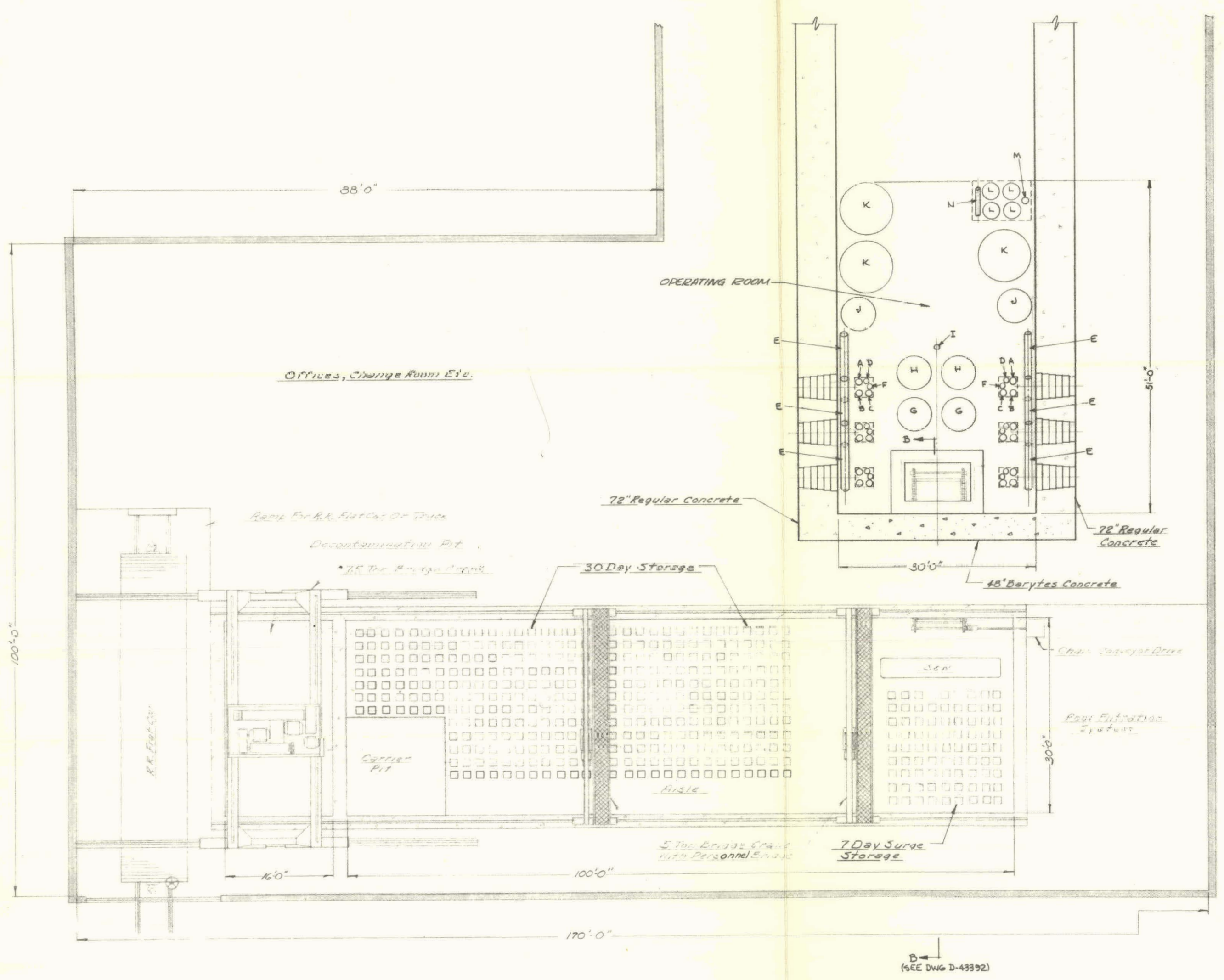

UNCLASSIFIED ORNL-LR-DWG 63321

Fig. A.3. Sulfex chemical head-end process: plant first floor plan. 
$-35-$

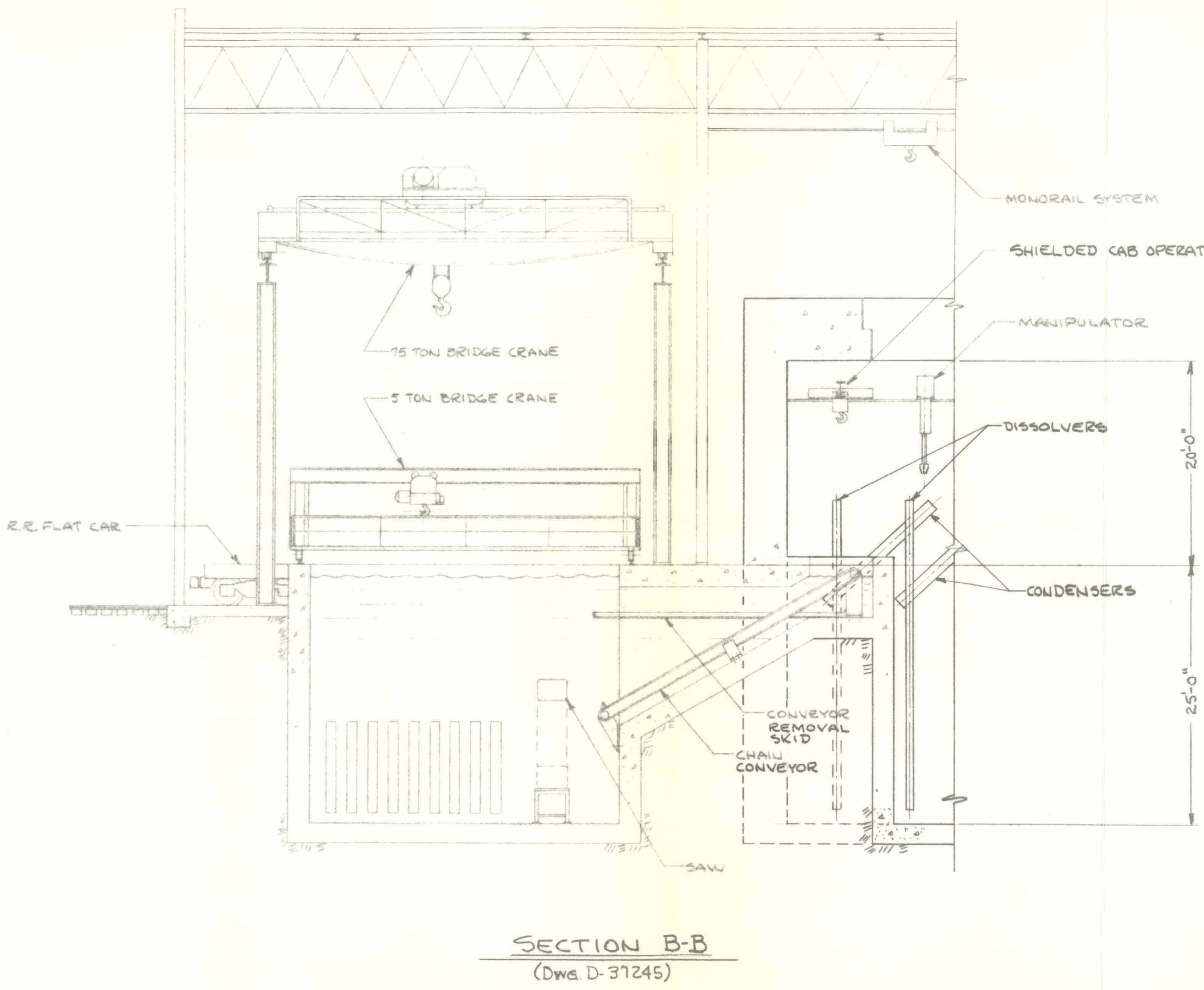

UNCLASSIFIED ORNL-LR-DWG 63322

Fig. A.4. Sulfex chemical head-end process: sectional elevation. 


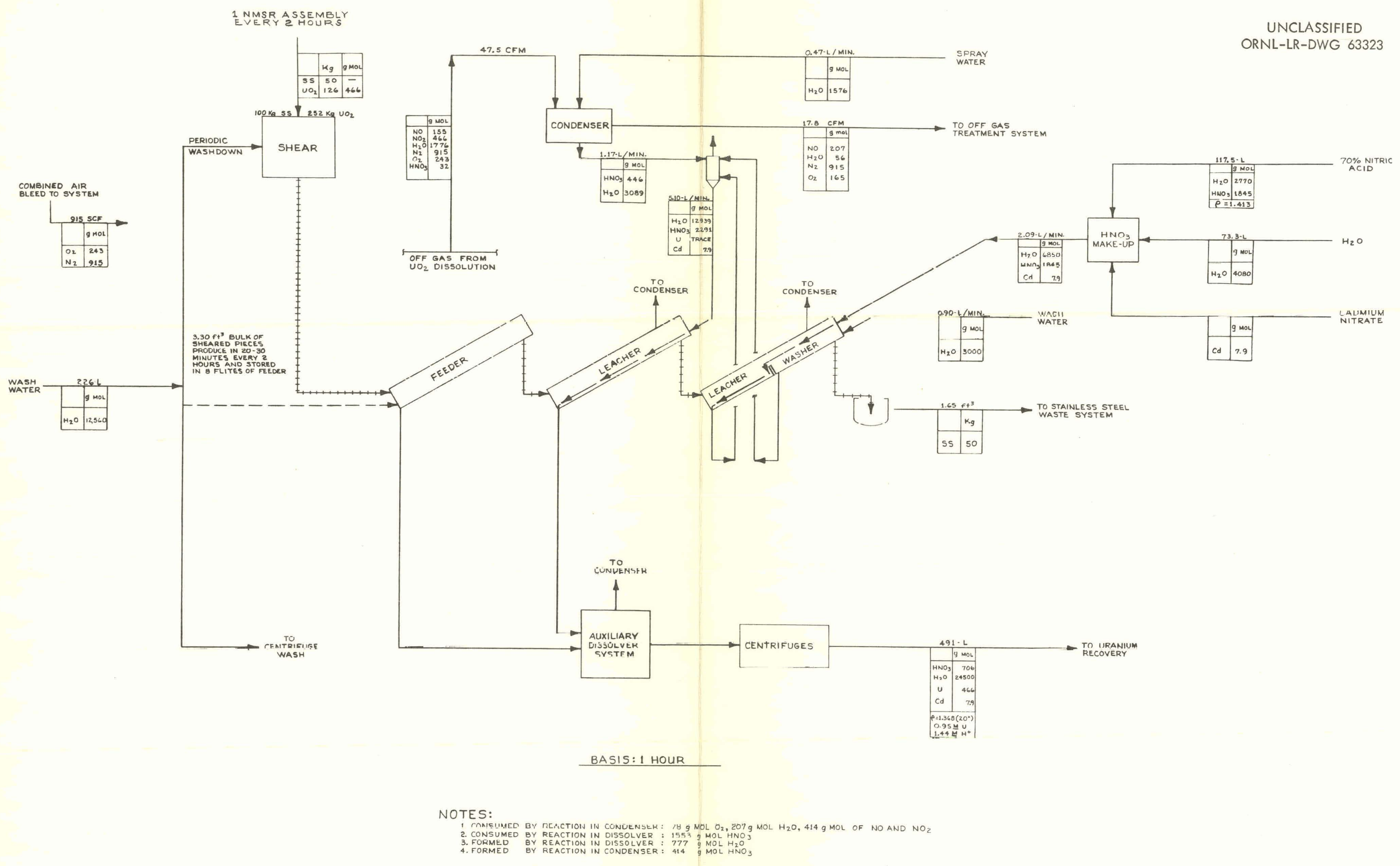

Fig. A.5. Mechanical head-end process: material balance flowsheet. 


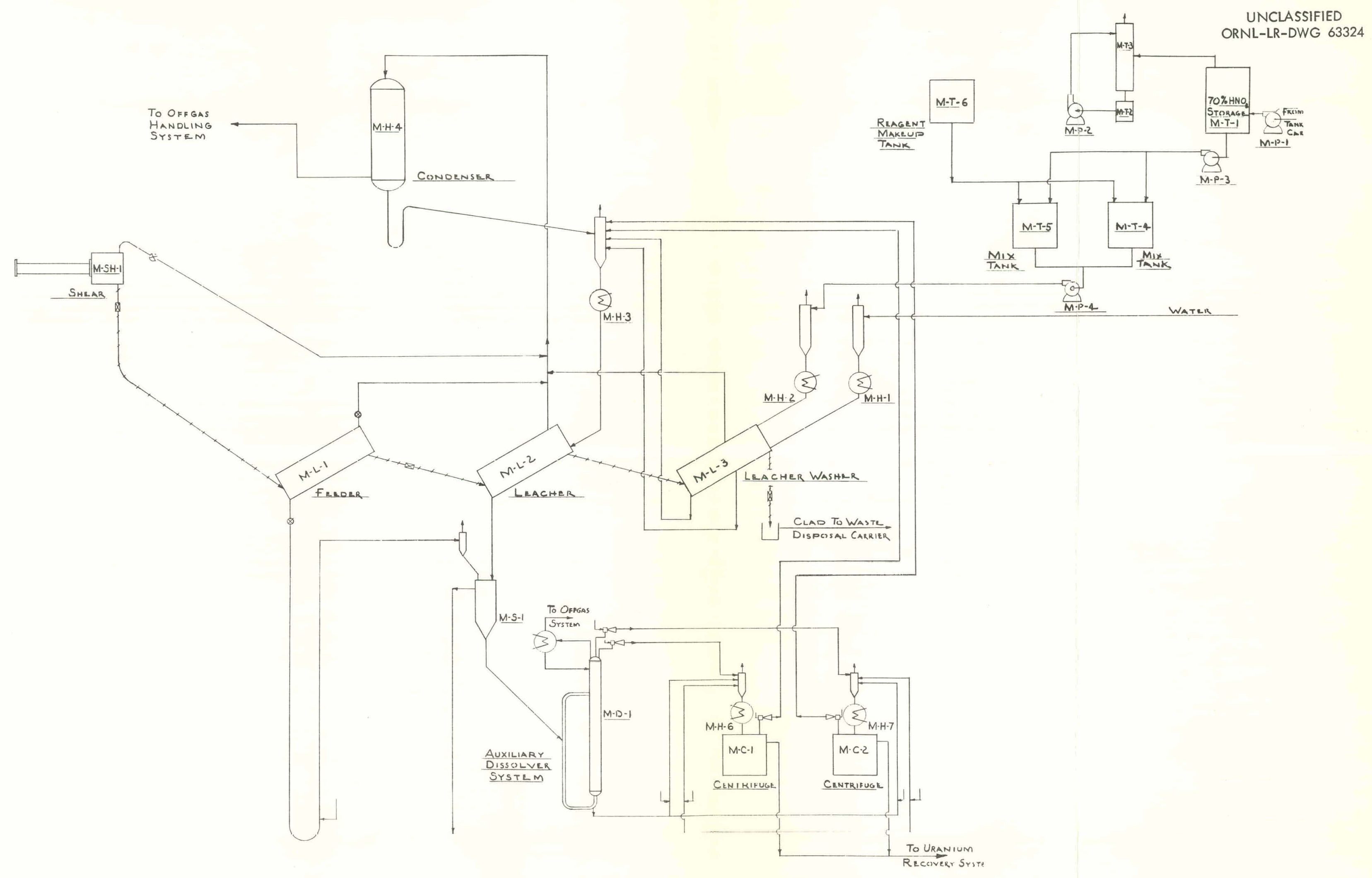

Fig. A.6. Mechanical head-end process: equipment flowsheet. 


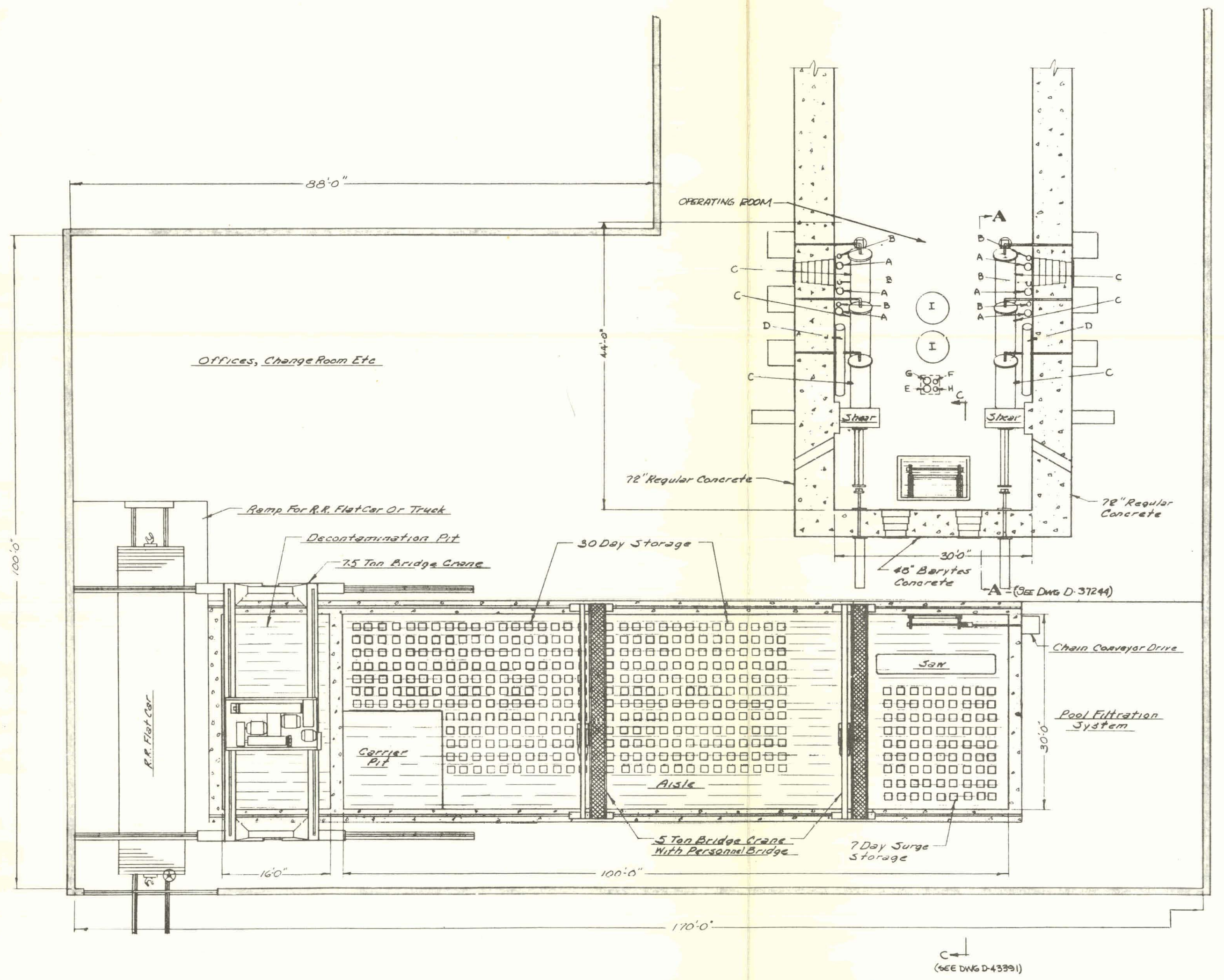

UNCLASSIFIED ORNL-LR-DWG 63325

Fig. A.7. Mechanical head-end process: plant first floor plan. 


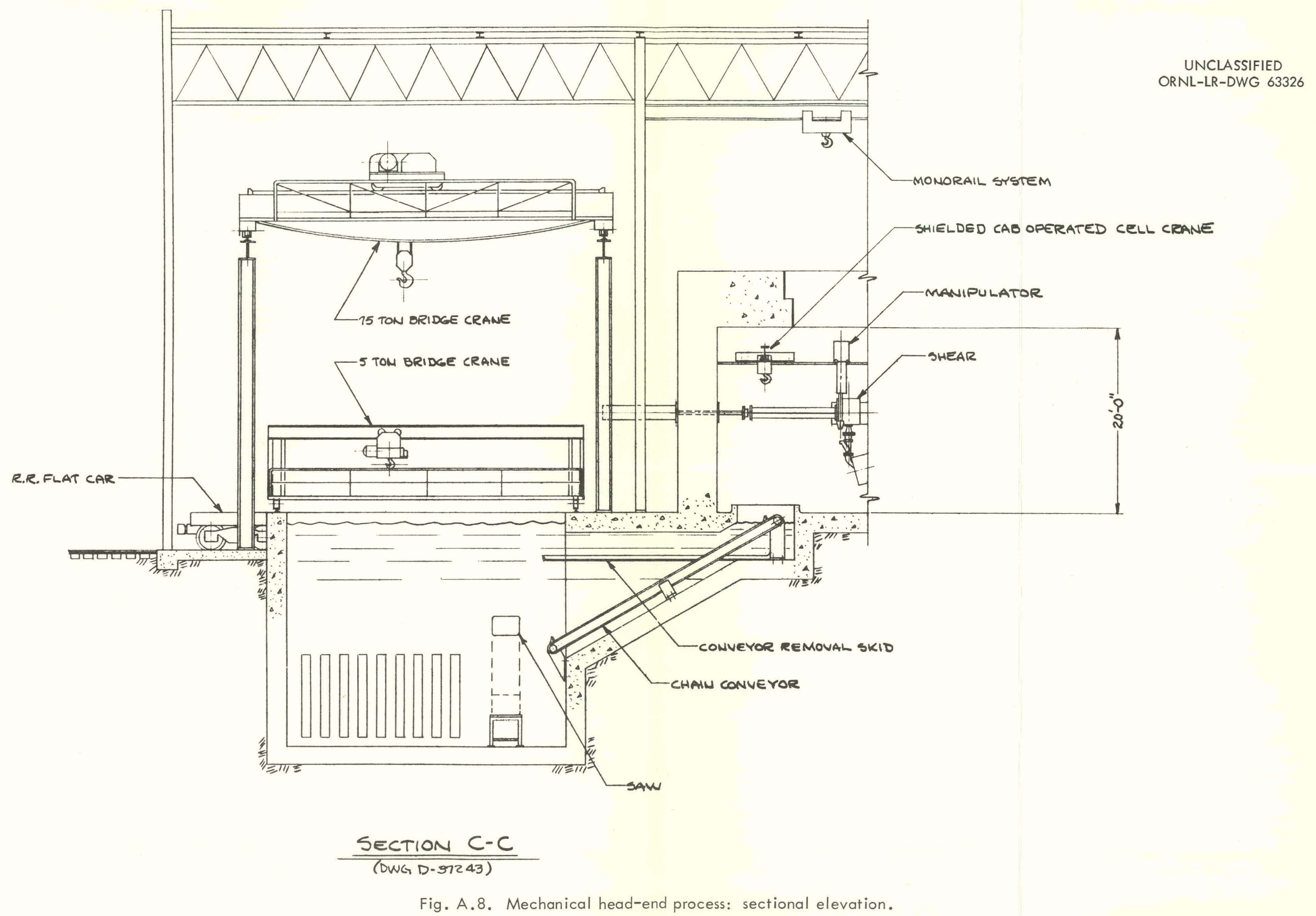




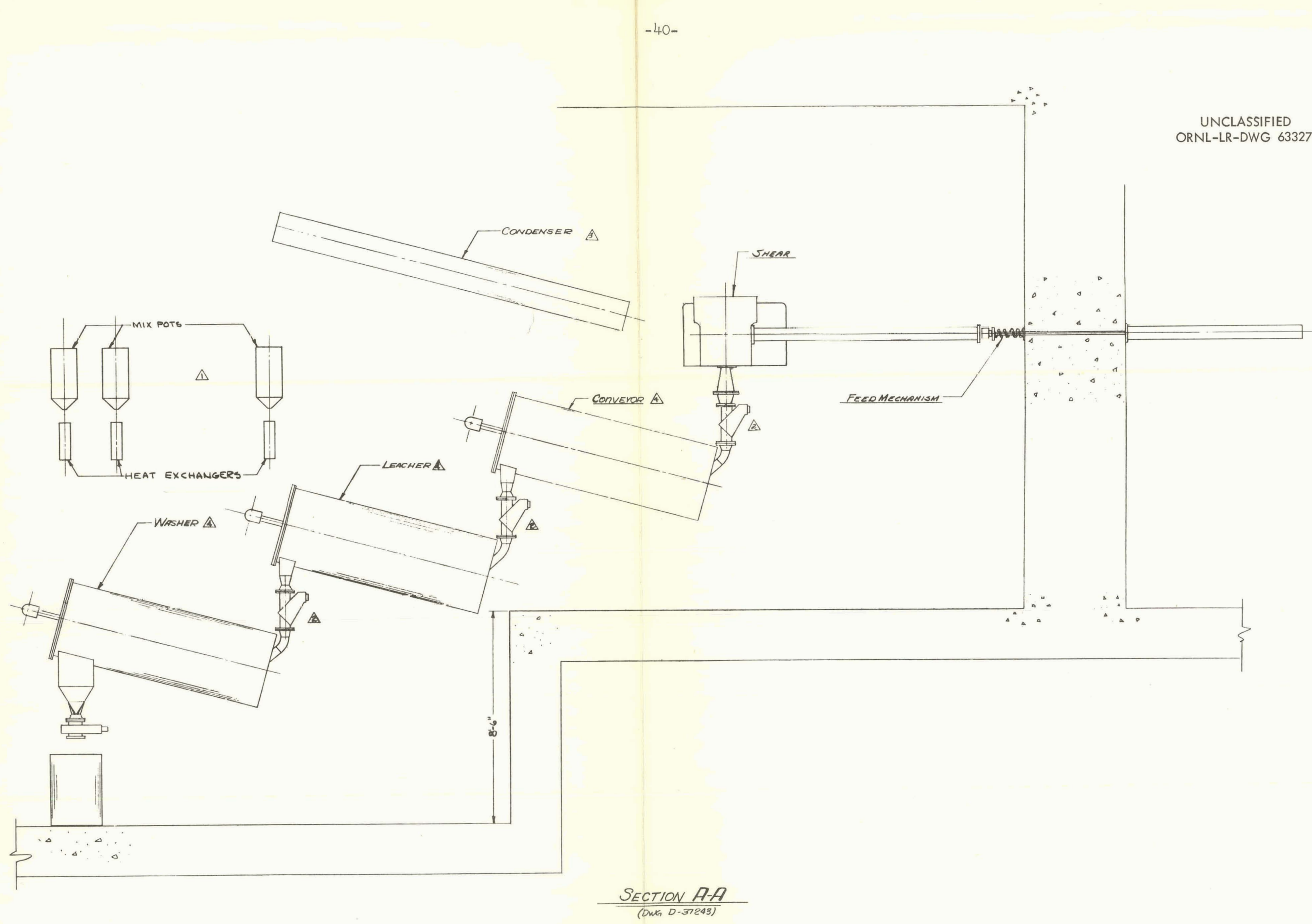

Fig. A.9. Mechanical head-end process: sectional elevation. 


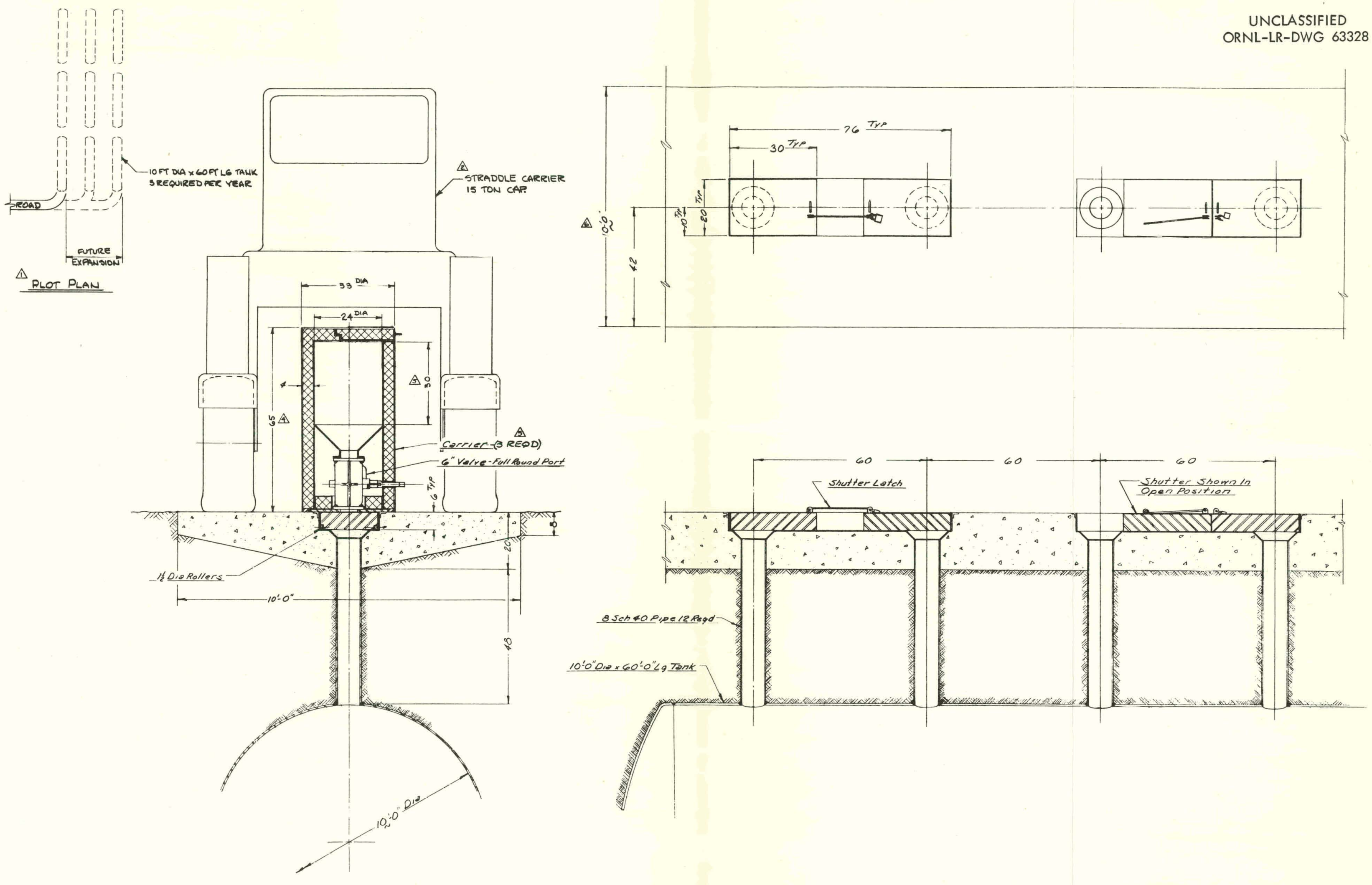

Fig. A.10. Mechanical head-end process: waste disposal. 
Table Al. Sulfex Equipment Cost at Engineering News Record Index of 813

\begin{tabular}{|c|c|c|c|c|c|}
\hline No. & Quantity & Description & Material & $\begin{array}{l}\text { Unit } \\
\text { Cost }\end{array}$ & $\begin{array}{l}\text { Total } \\
\text { Cost }\end{array}$ \\
\hline \multicolumn{6}{|c|}{ Nonradioactive Equipment (Installed) } \\
\hline$S-T-1$ & 1 & $\begin{array}{l}\mathrm{H}_{2} \mathrm{SO}_{4} \text { storage tank, } \\
75,000 \text { gal }\end{array}$ & Mild steel & $\$ 18,000$ & $\$ 18,000$ \\
\hline$S-T 2,3$ & 2 & $\begin{array}{l}\mathrm{H}_{2} \mathrm{SO}_{4} \text { mix t.ank, 2,500 } \\
\text { gal with agitator }\end{array}$ & Nlonel & 58,600 & 117,200 \\
\hline $\mathrm{S}-\mathrm{T}-4$ & 1 & $\begin{array}{l}\mathrm{H}_{3} \mathrm{BO}_{3}-\mathrm{HCOOH} \text { mix tank, } \\
1,000 \text { gal with agitator }\end{array}$ & 304 SS & 9,000 & 9,000 \\
\hline$S-T-5$ & 1 & $\begin{array}{l}\mathrm{HNO}_{3} \text { storage tank, } \\
2,500 \text { gal }\end{array}$ & 304 SS & 32,000 & 32,000 \\
\hline$S-T-6$ & 1 & $\begin{array}{l}\text { Scrubber surge tank, } \\
30 \text { gal }\end{array}$ & 304 SS & 760 & 760 \\
\hline S-T-7 & 1 & $\begin{array}{l}\text { Packed scrubber, } 6 \text { in. } \\
\text { dia } 4 \text { ft with packing }\end{array}$ & 304 SS & 780 & 780 \\
\hline S-T-8,9 & 2 & $\begin{array}{l}\mathrm{HNO}_{3} \text { mix tank, } 400 \text { gal, } \\
\text { with agitator }\end{array}$ & 304 SS & 5,500 & 11,000 \\
\hline $\mathrm{S}-\mathrm{T}-10$ & 1 & $\begin{array}{l}\mathrm{Cd}\left(\mathrm{NO}_{3}\right)_{2} \text { mix tank, } 100 \\
\text { gal with agitator }\end{array}$ & 304 SS & 3,100 & 3,100 \\
\hline S-T-11 & 1 & $\begin{array}{l}\mathrm{NaOH} \text { storage tank, } \\
140,000 \text { हal }\end{array}$ & Mild steel & 24,400 & 24,400 \\
\hline $\mathrm{S}-\mathrm{T}-12$ & 1 & $\begin{array}{l}\mathrm{NaOH} \text { supplying tank, } \\
200 \text { gal }\end{array}$ & Mild steel & 840 & 840 \\
\hline S-P-I & 2 & $\begin{array}{l}\mathrm{H}_{2} \mathrm{SO}_{4} \text { loading pump } \\
\quad \text { and drive, } 20 \mathrm{gpm} \text {, } \\
10 \mathrm{hp}\end{array}$ & 304 SS & 1,620 & 3,240 \\
\hline$S-P-2$ & 2 & $\begin{array}{l}\mathrm{H}_{2} \mathrm{SO}_{4} \text { batch loading } \\
\text { pump and drive, } 10 \\
\text { gpm, } 5 \mathrm{hp}\end{array}$ & 304 SS & 1,290 & 2,580 \\
\hline S-P-3 & 2 & $\begin{array}{l}\mathrm{HNO}_{3} \text { loading pump and } \\
\text { drive, } 10 \mathrm{ggm}, 3 \mathrm{hp}\end{array}$ & 304 SS & 1,200 & 2,400 \\
\hline S-P-4 & 2 & $\begin{array}{l}\text { Scrubber circulating } \\
\text { pump, } 2 \text { gpm, I/2 hp }\end{array}$ & $304 \mathrm{SS}$ & 800 & 1,600 \\
\hline$S-P-5$ & 2 & $\begin{array}{l}\mathrm{HNO}_{3} \text { batch loading pump } \\
\text { and drive, } 3 \mathrm{gpm}, 1 \mathrm{hp}\end{array}$ & 304 SS & 920 & 1,840 \\
\hline S-P-6 & 3 & $\begin{array}{l}\mathrm{NaOH} \text { loading pump and } \\
\text { drive, } 20 \mathrm{gpm}, 5 \mathrm{hp}\end{array}$ & 304 SS & 1,440 & 4,320 \\
\hline S-P-7 & 2 & $\begin{array}{l}\mathrm{NaOH} \text { batch loading pump } \\
\text { and drive, } 3 \mathrm{gpm}, 1 \mathrm{hp}\end{array}$ & 304 SS & 925 & 1,850 \\
\hline S-P-8 & 2 & $\begin{array}{l}\mathrm{NaOH} \text { feed pump and drive, } \\
3 \mathrm{gpm}, \mathrm{l} \mathrm{hp}\end{array}$ & 304 SS & 925 & 1,850 \\
\hline
\end{tabular}


Table Al. (Continued)

\begin{tabular}{|c|c|c|c|c|c|c|}
\hline No. & Quantity & Description & Material & & $\begin{array}{l}\text { Unit } \\
\text { Cost }\end{array}$ & $\begin{array}{l}\text { Total } \\
\text { Cost }\end{array}$ \\
\hline S-P-9 & 8 & $\begin{array}{l}\mathrm{H}_{2} \mathrm{SO}_{4} \text { dissolver feed } \\
\text { pump and drive, } 2.5 \\
\text { gpm, } 3 / 4 \mathrm{hp}\end{array}$ & Nionel & $\$$ & 1,410 & $\$ 11,280$ \\
\hline S-P-10 & 4 & $\begin{array}{l}\mathrm{HNO}_{3} \text { dissolver feed } \\
\text { pump and drive, I gpm, } \\
\mathrm{l} / \mathrm{2} \mathrm{hp}\end{array}$ & 304 sS & & 715 & 2,860 \\
\hline \multirow[t]{2}{*}{$\mathrm{S}-\mathrm{H}-\mathrm{I}$} & 1 & $\begin{array}{l}\mathrm{H}_{2} \mathrm{SO}_{4} \text { mix tank condens- } \\
\quad \mathrm{er}, 10 \mathrm{ft}^{2}\end{array}$ & 304 SS & & 1,260 & 1,260 \\
\hline & & Tnstalled & & & - & $\$ 252,160$ \\
\hline
\end{tabular}

Radioactive Equipment (Delivered)

\begin{tabular}{|c|c|c|c|c|c|}
\hline S-D-1-6 & 6 & Dissolver, steam jacket & $\begin{array}{l}\text { Nionel, SS } \\
\text { jacket }\end{array}$ & 14,000 & 84,000 \\
\hline$S-D-7$ & 1 & Waste slurry dissolver & $\begin{array}{l}\text { Nionel, SS } \\
\text { jacket }\end{array}$ & 7,000 & 7,000 \\
\hline$S-T-13,14$ & 2 & Wash hold tank, 800 gal & 304 SS & 4,040 & 8,080 \\
\hline$S-T-15-17$ & 3 & $\begin{array}{l}\text { Neutralization hold tank, } \\
\text { 3,000 gal, safe bottom }\end{array}$ & Nionel & 18,600 & 55,800 \\
\hline$S-T-18-21$ & 4 & $\begin{array}{l}\text { Neutralization tank, } \\
\text { cooling jacket, } 200 \\
\text { gal }\end{array}$ & $\begin{array}{l}\text { Nionel, } 304 \\
\text { SS jacket }\end{array}$ & 5,020 & 20,080 \\
\hline S-P-11 & 2 & $\begin{array}{l}\text { Waste pump and drive, } \\
12 \mathrm{gpm}, 5 \mathrm{hp}\end{array}$ & Nionel & 1,820 & 3,640 \\
\hline $\mathrm{S}-\mathrm{H}-2-7$ & 6 & $\begin{array}{l}\text { Dissolver feed preheater, } \\
10 \mathrm{ft}^{2}\end{array}$ & $\begin{array}{l}\text { Nionel, } 304 \\
\text { SS shell }\end{array}$ & 1,200 & 7,200 \\
\hline $\mathrm{S}-\mathrm{H}-8-13$ & 6 & Product cooler, $12 \mathrm{ft}^{2}$ & $\begin{array}{l}\text { Nionel, } 304 \\
\text { SS shell }\end{array}$ & 1,330 & 7,980 \\
\hline S-H-14-19 & 6 & $\begin{array}{l}\text { Dissolver condensers, } \\
250 \mathrm{ft}^{2}\end{array}$ & $\begin{array}{l}\text { Nionel, } 304 \\
\text { SS shell }\end{array}$ & 16,600 & 99,600 \\
\hline $\mathrm{S}-\mathrm{H}-20$ & 1 & $\begin{array}{l}\text { Waste slurry dissolver } \\
\text { condenser, } 250 \mathrm{ft}^{2}\end{array}$ & $\begin{array}{l}\text { Nionel, } 304 \\
\text { SS shell }\end{array}$ & 2,380 & 2,380 \\
\hline $\mathrm{S}-\mathrm{H}-21$ & 1 & Waste precooler, $55 \mathrm{ft}^{2}$ & $\begin{array}{l}\text { Nionel, } 304 \\
\text { SS shell }\end{array}$ & 3,220 & 3,220 \\
\hline $\mathrm{S}-\mathrm{H}-22$ & 1 & $\begin{array}{l}\text { Neutralization condenser, } \\
10 \mathrm{ft}^{2}\end{array}$ & $\begin{array}{l}\text { Nionel, } 304 \\
\text { SS shell }\end{array}$ & 1,360 & 1,360 \\
\hline$S-S-1-6$ & 6 & $\begin{array}{l}\text { Dissolver settlers, } 1 \mathrm{ft} \\
\text { dia } \times 5 \mathrm{ft}\end{array}$ & Nionel. & 1,300 & 7,800 \\
\hline$S-C-1-2$ & 2 & $\begin{array}{l}\text { Centrifuge for } \mathrm{H}_{2} \mathrm{SO}_{4} \\
48 \text { in dia }\end{array}$ & Nionel & 130,000 & 260,000 \\
\hline $\mathrm{S}-\mathrm{C}-3,4$ & 2 & $\begin{array}{l}\text { Centrifuge for } \mathrm{HNO}_{3}, \\
48 \text { in. dia }\end{array}$ & 304 SS & 72,500 & 145,000 \\
\hline
\end{tabular}


Table Al. (Continued)

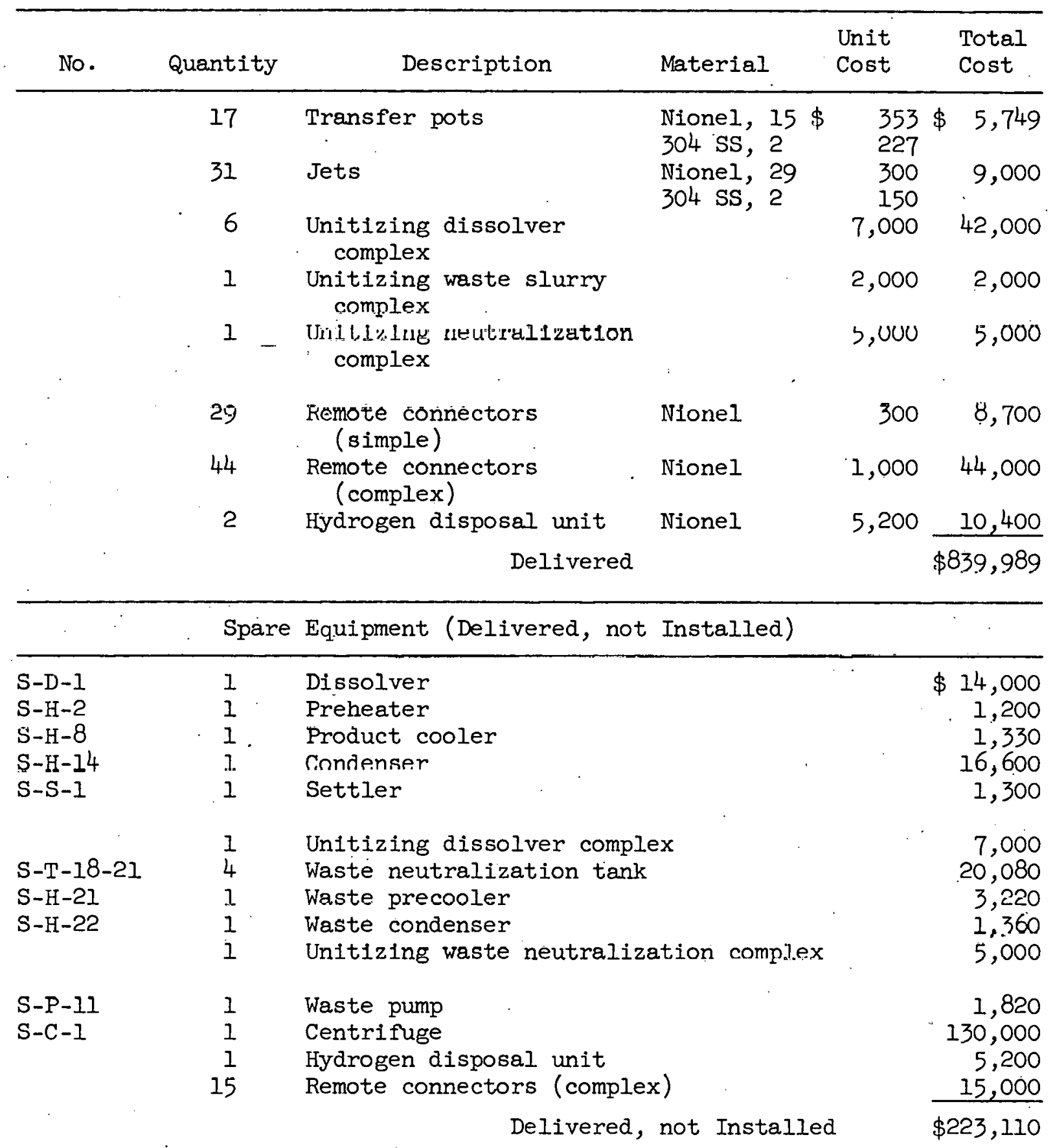


Table A2. Shear-Leach Equipment Cost at Engineering News Record Index of 813

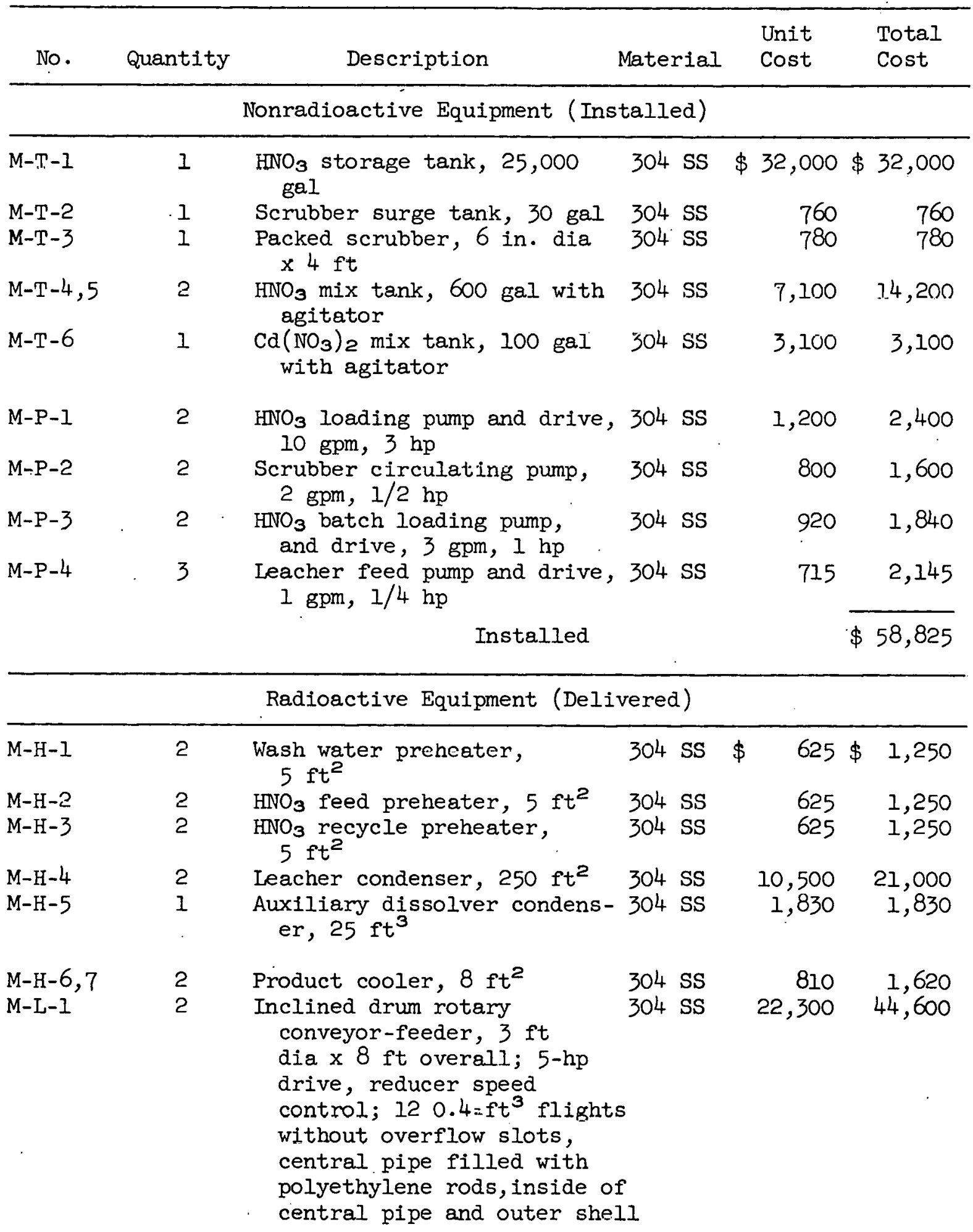


Table A2. (Continued)

\begin{tabular}{|c|c|c|c|c|c|}
\hline No. & Quantity & Description & Material & $\begin{array}{l}\text { Unit } \\
\text { Cost }\end{array}$ & $\begin{array}{l}\text { Total } \\
\text { Cost }\end{array}$ \\
\hline & & $\begin{array}{l}\text { covered full length with } \\
20 \text {-mil Cd sheet encapsu- } \\
\text { lated in } 304 \text { SS; liquid } \\
\text { drain, off-gas connection, } \\
\text { and solids valve }\end{array}$ & & & \\
\hline$M-L-2$ & 2 & 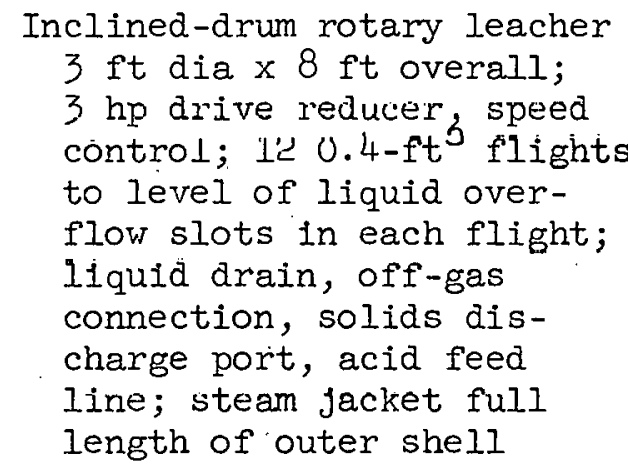 & 304 SS & $\$ 20,100$ & $\$ 40,200$ \\
\hline$M-L-3$ & 2 & $\begin{array}{l}\text { Inclined-drum rotary leach- } \\
\text { er-washer; same as M-L-2 } \\
\text { with porous draining } \\
\text { section in 8th flight, } \\
\text { wash water feed line }\end{array}$ & 304 SS & 21,200 & 42,400 \\
\hline$M-D-1$ & 1 & $\begin{array}{l}\text { Auxiliary dissolver } 6 \text { in. } \\
\text { dia } x 12 \mathrm{ft} \text {, steam jacket }\end{array}$ & 304 SS & 5,500 & 5,500 \\
\hline \multirow{5}{*}{$\begin{array}{l}\text { M-S-1 } \\
\text { M-C-1,2 }\end{array}$} & 1 & Settler, $1 \mathrm{ft}$ dia $\times 5 \mathrm{ft}$ & 304 SS & $\cdot 650$ & 650 \\
\hline & $\begin{array}{l}2 \\
6 \\
4\end{array}$ & $\begin{array}{l}\text { Centr1fuge, } 48 \text { in. dia } \\
\text { Transfer pots } \\
\text { Jets }\end{array}$ & $\begin{array}{l}304 \text { SS } \\
304 \text { SS } \\
304 \text { SS }\end{array}$ & $\begin{array}{r}72,500 \\
227 \\
150\end{array}$ & $\begin{array}{r}145,000 \\
1,362 \\
600\end{array}$ \\
\hline & 1 & $\begin{array}{l}\text { Unitizing auxiliary dis- } \\
\text { solver, complex }\end{array}$ & & 3,000 & 3,000 \\
\hline & 40 & Remote connectors (simple) & 304 SS & 270 & 10,800 \\
\hline & 21 & Remote connectors (complex) & 304 SS & 910 & 19,110 \\
\hline \multirow[t]{3}{*}{ M-SL-I } & 2 & $\begin{array}{l}\text { Shear complex: } 500 \text { ton-shear, } \\
300-\text { hp drive, hydraulic } \\
\text { system } 12 \text { in. thrust; } \\
\text { valve, feed mechanism, } \\
\text { water spray-down system, } \\
\text { 2-in. blade and anvil }\end{array}$ & & 210,000 & 420,000 \\
\hline & 12 & $\begin{array}{l}\text { Feed envelopes for fuel } \\
\text { elements }\end{array}$ & & 400 & 4,800 \\
\hline & & Delivered & & & $\$ 766,222$ \\
\hline
\end{tabular}


Table A2. (Continued)

\begin{tabular}{|c|c|c|c|c|}
\hline No. & Quantity & Description & $\begin{array}{l}\text { Unit } \\
\text { Cost }\end{array}$ & $\begin{array}{l}\text { Total } \\
\text { Cost }\end{array}$ \\
\hline \multicolumn{5}{|c|}{ Spare Equipment (Delivered, not Installed) } \\
\hline \multirow[t]{5}{*}{$\mathrm{M}-\mathrm{C}-1$} & 1 & Centrifuge & $\$ 72,500$ & $\$ 72,500$ \\
\hline & 10 & Remote connectors (complex) & 910 & 9,100 \\
\hline & 4 & $\begin{array}{l}\text { Blade and anvil set for } \\
\text { shear }\end{array}$ & 3,000 & 12,000 \\
\hline & 2 & $\begin{array}{l}\text { Sets of gibs (wearing } \\
\text { surfaces) }\end{array}$ & 5,000 & 10,000 \\
\hline & & Delivered, not Inste & lled & $\$ 103,600$ \\
\hline
\end{tabular}


Table A3. Annual Costs of Materials and Utilities

\begin{tabular}{|c|c|c|c|c|}
\hline Materials & Sulfex & $\$$ & Shear-Leach & $\$$ \\
\hline $\begin{array}{l}\mathrm{HNO}_{3}(70 \%) \\
\mathrm{Cd}\left(\mathrm{NO}_{3}\right)_{2}\end{array}$ & $\begin{array}{l}1321 \text { tons/yr at } \$ 138 / \text { ton } \\
\left\{\begin{array}{l}\mathrm{CdO}^{2} 7230 \mathrm{lb} / \mathrm{yr} \text { at } \$ 1.77 \mathrm{lb} \\
\mathrm{HNO}_{3}(100 \%) 3.54 \text { tons/yr at } \\
\$ 197 / \text { ion }\end{array}\right.\end{array}$ & $\begin{array}{r}182,500 \\
13,478\end{array}$ & $\begin{array}{l}1321 \text { tons/yr at } \$ 138 / \text { ton } \\
\left\{\begin{array}{l}\mathrm{CdO} 72301 \mathrm{~b} / \mathrm{yr} \text { at } \$ 1.77 / 1 \mathrm{~b} \\
\mathrm{INO}_{3}(100 \%) 3.54 \text { tons } / \mathrm{yr} \text { at } \\
\$ 197 / \text { ton }\end{array}\right.\end{array}$ & $\begin{array}{r}182,500 \\
13,478\end{array}$ \\
\hline $\begin{array}{l}\mathrm{H}_{3} \mathrm{BO}_{3} \\
\mathrm{H}_{2} \mathrm{SO}_{4} \text { (93\%) } \\
\text { Formic acid (90\%) } \\
\mathrm{NaOH} \mathrm{(50 \% )} \\
\text { Nitrogen gas } \\
\text { Hydrogen gas } \\
\text { Oxygen gas }\end{array}$ & $\begin{array}{l}83.8 \text { tons } / \mathrm{yr} \text { at } \$ 160 / \text { ton } \\
5710 \text { tons } / \mathrm{yr} \text { at } \$ 32 / \text { ton } \\
69.3 \text { tons } / \mathrm{yr} \text { at } \$ 0.19 / 1 \mathrm{~b} \\
8870 \text { tons } / \mathrm{yr} \text { at } \$ 64 / \text { ton } \\
505 \mathrm{MSCF} / \mathrm{yr} \text { at } \$ 10 / 1000 \mathrm{ft}^{3} \\
\left\{\begin{array}{l}2 \mathrm{cylinders} / \mathrm{day}, 300 \mathrm{days} / \mathrm{yr} \\
\text { at } \$ 20 / \mathrm{cy} 1 \text { inder }\end{array}\right. \\
3130 \mathrm{MSCF} / \mathrm{yr} \text { at } \$ 2.40 / 1000 \mathrm{ft}^{3}\end{array}$ & $\begin{array}{r}13,400 \\
182,800 \\
26,300 \\
567,000 \\
5,050 \\
6,000\end{array}$ & 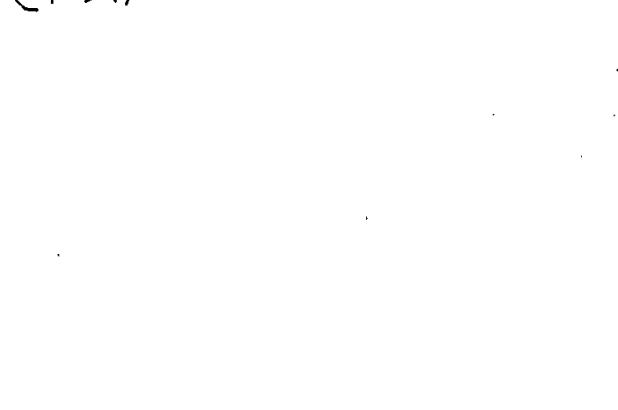 & $\$ 195,978$ \\
\hline
\end{tabular}

\begin{tabular}{|c|c|c|c|c|c|}
\hline \multirow[b]{2}{*}{ Utility } & \multirow[b]{2}{*}{$\begin{array}{l}\text { Unit Cost } \\
\text { (dollars) }\end{array}$} & \multicolumn{2}{|c|}{ Sulfex } & \multicolumn{2}{|c|}{ Shear-Leach } \\
\hline & & $\begin{array}{c}\text { Amount } \\
\text { in } \mathrm{MM} / \text { year }\end{array}$ & $\begin{array}{c}\text { Cost } \\
\text { (dollars) }\end{array}$ & $\begin{array}{c}\text { Amount } \\
\text { in MM/year }\end{array}$ & $\begin{array}{c}\text { Cost } \\
\text { (dollars) }\end{array}$ \\
\hline $\begin{array}{l}\text { Steam } \\
\text { Air } \\
\text { Water } \\
\text { Electricity }\end{array}$ & $\begin{array}{l}0.70 / 1000 \mathrm{lb}^{3} \\
0.03 / 1000 \mathrm{ft}^{3} \\
0.05 / 1000 \mathrm{gal}^{2} / \mathrm{kr} \mathrm{hr} \\
0.010 / 0\end{array}$ & $\begin{array}{c}6.1 \mathrm{lt} \\
7.8 \mathrm{sCF} \\
38.7 \text { gal } \\
0.273 \text { watt } \mathrm{hr}\end{array}$ & $\begin{array}{r}4,330 \\
234 \\
1,935 \\
2,730 \\
\end{array}$ & $\begin{array}{c}2.5 \mathrm{lb} \\
1.29 \mathrm{SCF} \\
10.1 \mathrm{gal} \\
0.397 \text { watt } \mathrm{hr}\end{array}$ & $\begin{array}{r}1,750 \\
39 \\
505 \\
3,970 \\
\end{array}$ \\
\hline & & & $\$ 9,229$ & & $\$ 6,264$ \\
\hline
\end{tabular}


Table A4. Annual Operating Labor Costs

(Excluding Supervision)

\begin{tabular}{|c|c|c|}
\hline Operation & $\begin{array}{l}\text { Sulfex } \\
\text { No. of men required }\end{array}$ & $\begin{array}{l}\text { Shear-Leach } \\
\text { No. of men required }\end{array}$ \\
\hline Ioad and operate shear & - & 2.5 \\
\hline Operate leacher system & - & 2 \\
\hline Operate 3 batch dissolvers & 2 & - \\
\hline Operate 3 batch dissolvers & 2 & - \\
\hline Makeup $\mathrm{HNO}_{3}$ & 1 & 1 \\
\hline Makeup $\mathrm{H}_{2} \mathrm{SO}_{4}$ & 1 & - \\
\hline Hydrogen disposal & 0.5 & - \\
\hline Receiving & 0.5 & 0.5 \\
\hline Operate 2 centrifuges & 2 & 2 \\
\hline Operate 2 centrifuges & 2 & - \\
\hline Waste slurry dissolver & 1 & 1 \\
\hline \multirow[t]{6}{*}{ Neutralization and hold tanks } & 2 & - \\
\hline & 14 & 9 \\
\hline & $\begin{array}{l}14 \text { men per shift, } \\
4 \text { shifts, } 56 \text { men } \\
\text { total }\end{array}$ & $\begin{array}{l}9 \text { men per shift, } \\
4 \text { shifts, } 36 \text { men } \\
\text { total }\end{array}$ \\
\hline & 56 men $x \frac{40 h r}{\operatorname{man} w k s} \times$ & 36 men $\times \frac{40 \mathrm{hr}}{\text { man wks }} \times$ \\
\hline & $\frac{52 \mathrm{wk}}{\mathrm{yr}} \times \$ 3.00 / \mathrm{hr}=$ & $\frac{52 \mathrm{wk}}{\mathrm{yr}} \times \$ 3.00 / \mathrm{hr}=$ \\
\hline & $\$ 349,000$ & $\$ 224,000$ \\
\hline
\end{tabular}




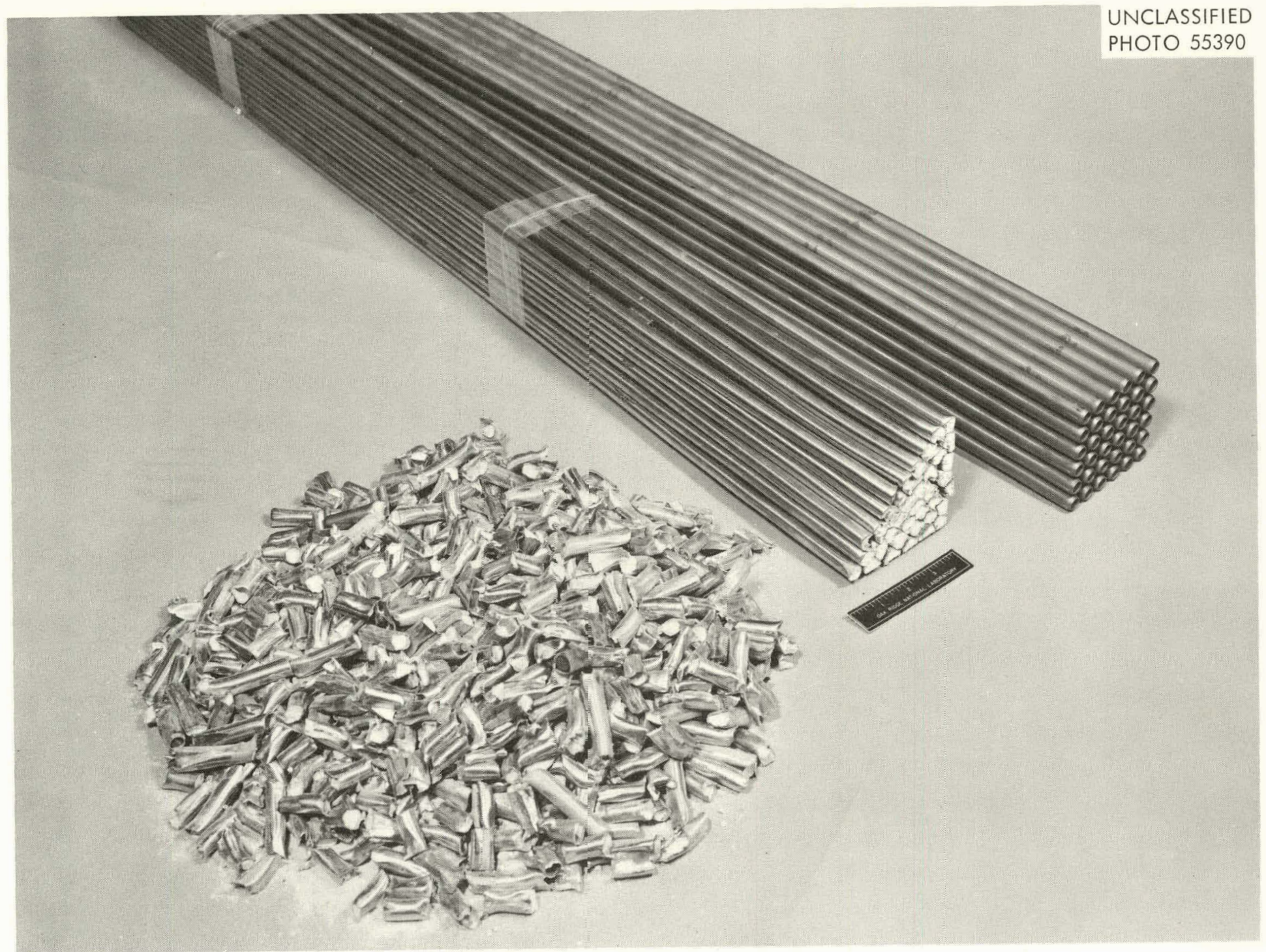

Fig. A-11. Fuel assemblies iporcelain-filled) and sheared pieces. 


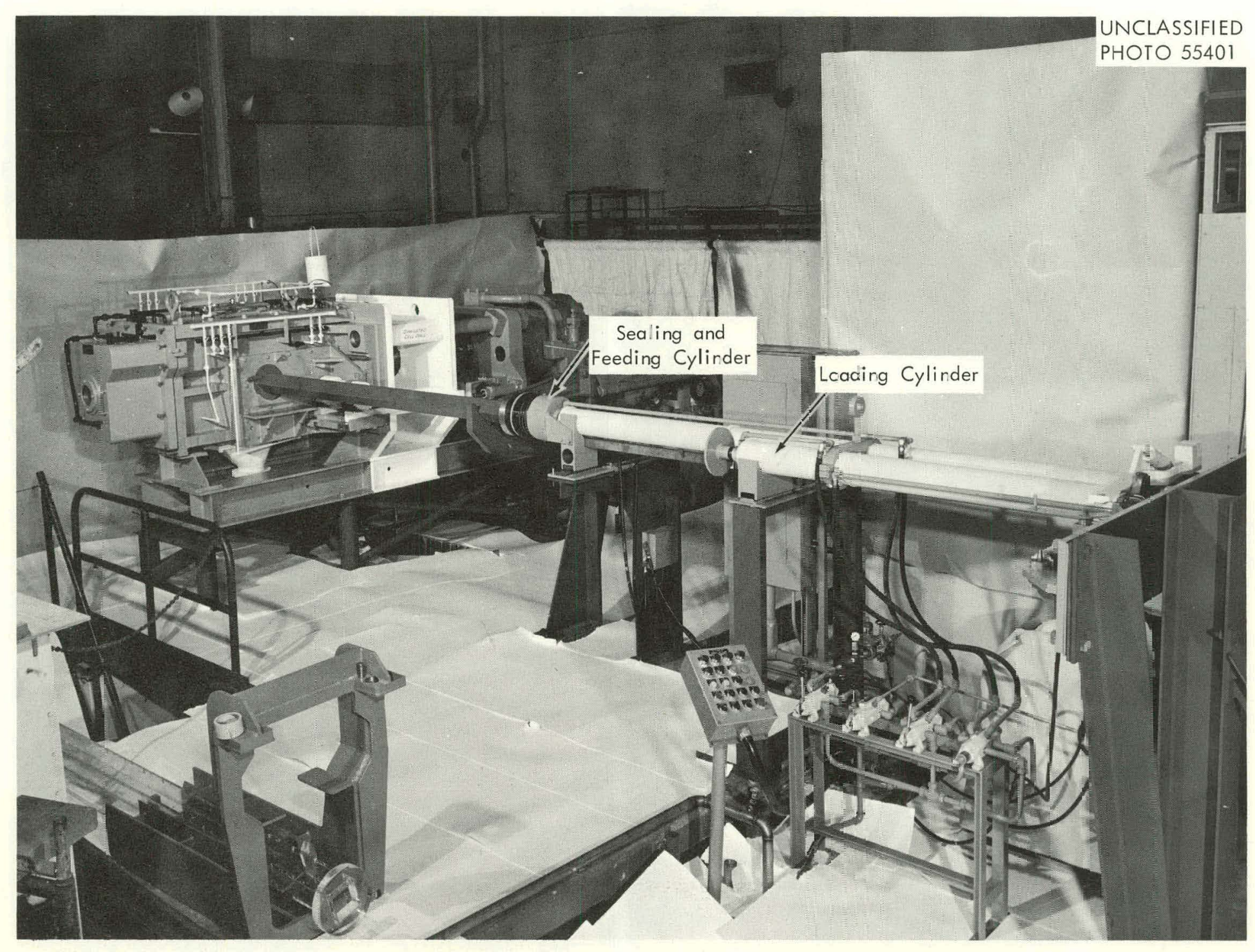

Fig. A-12. 250-Ton shear on test stand. 


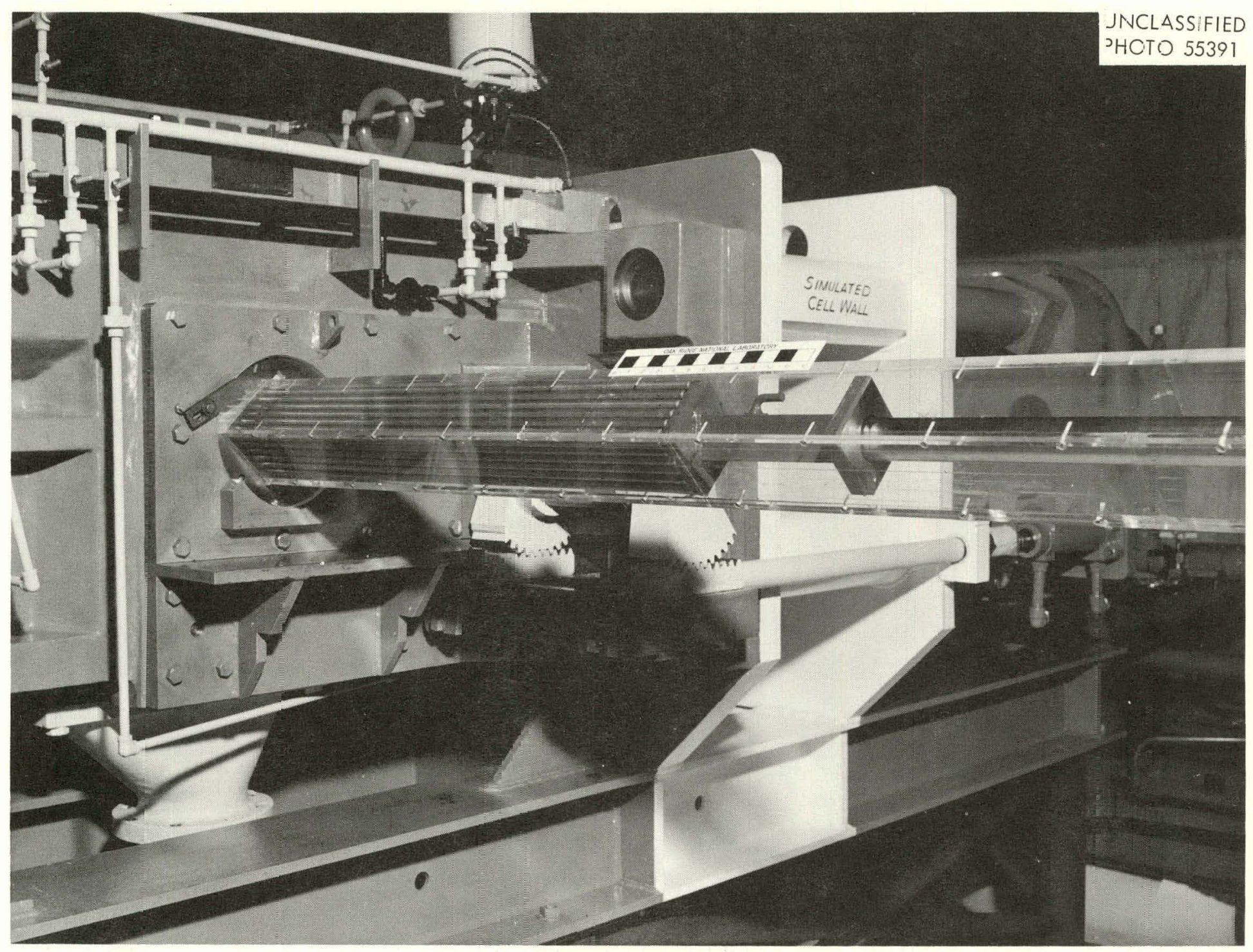

Fig. A-13. Fuel assembly insice plastic envelope being fed into shear by feed arn. 


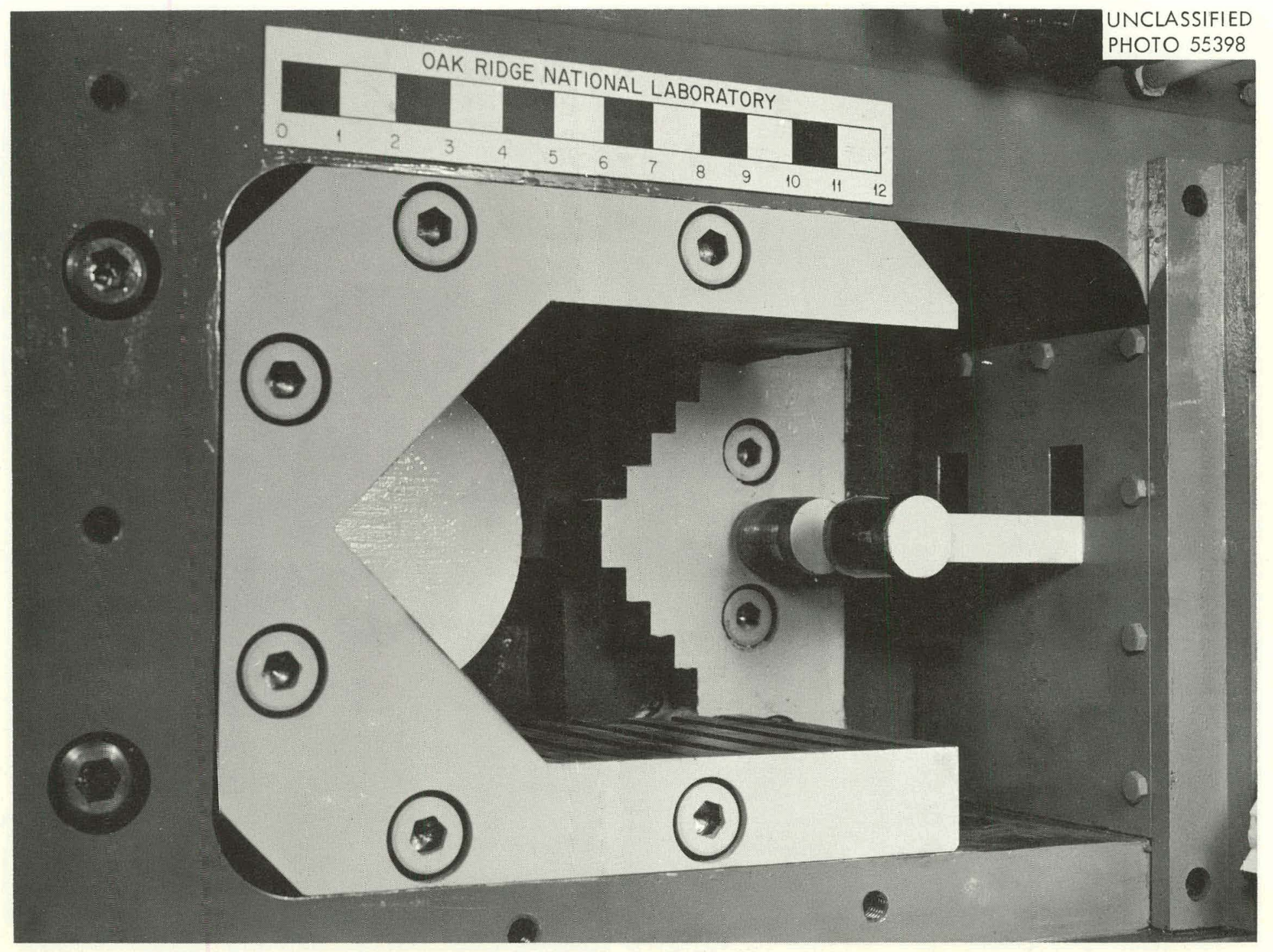

Fig. A-14. Fixed V-blade and moving stepped blade of shear with circular stop in background. 


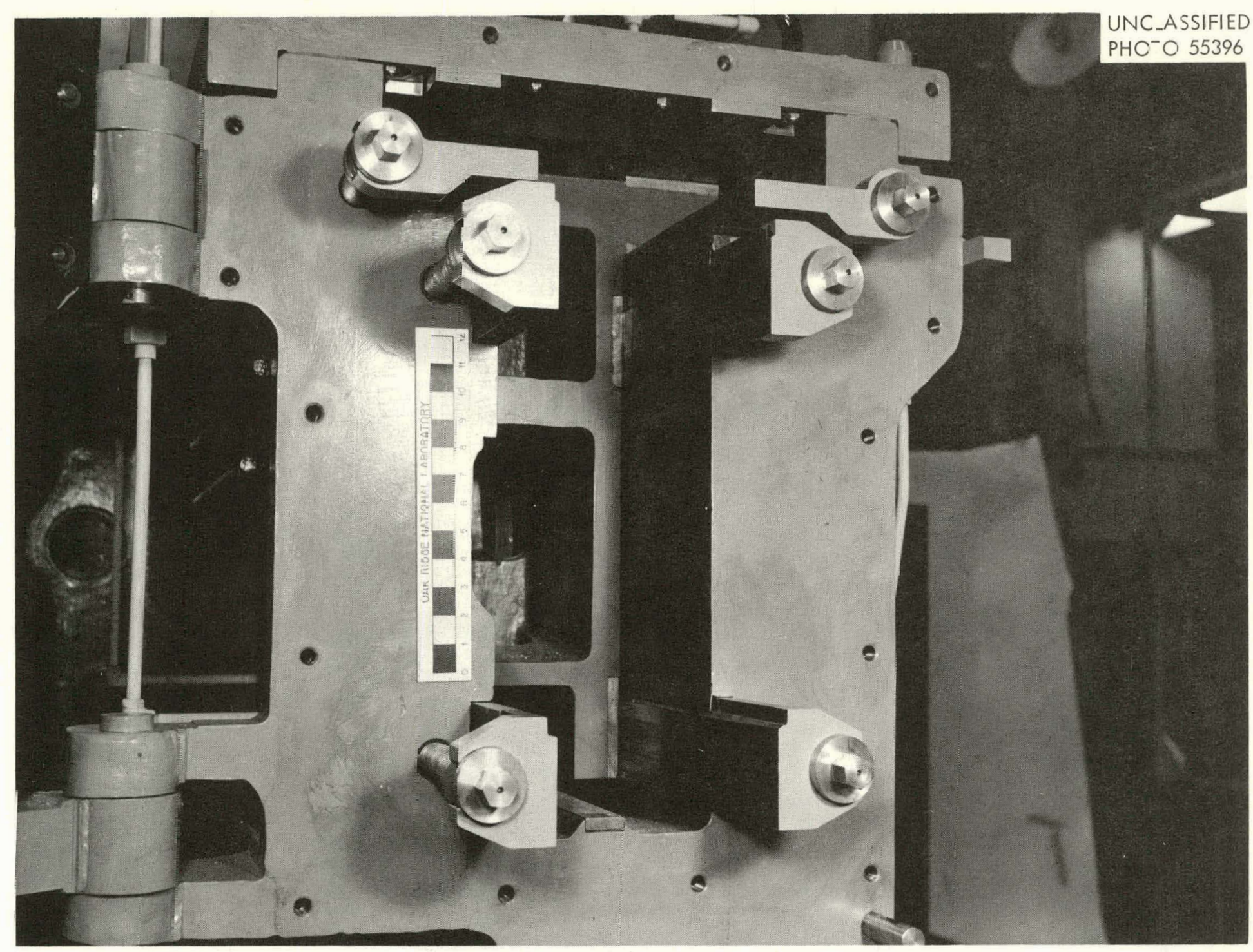

Fig. A-15. Shear with end housing open showing gibs and ram. 


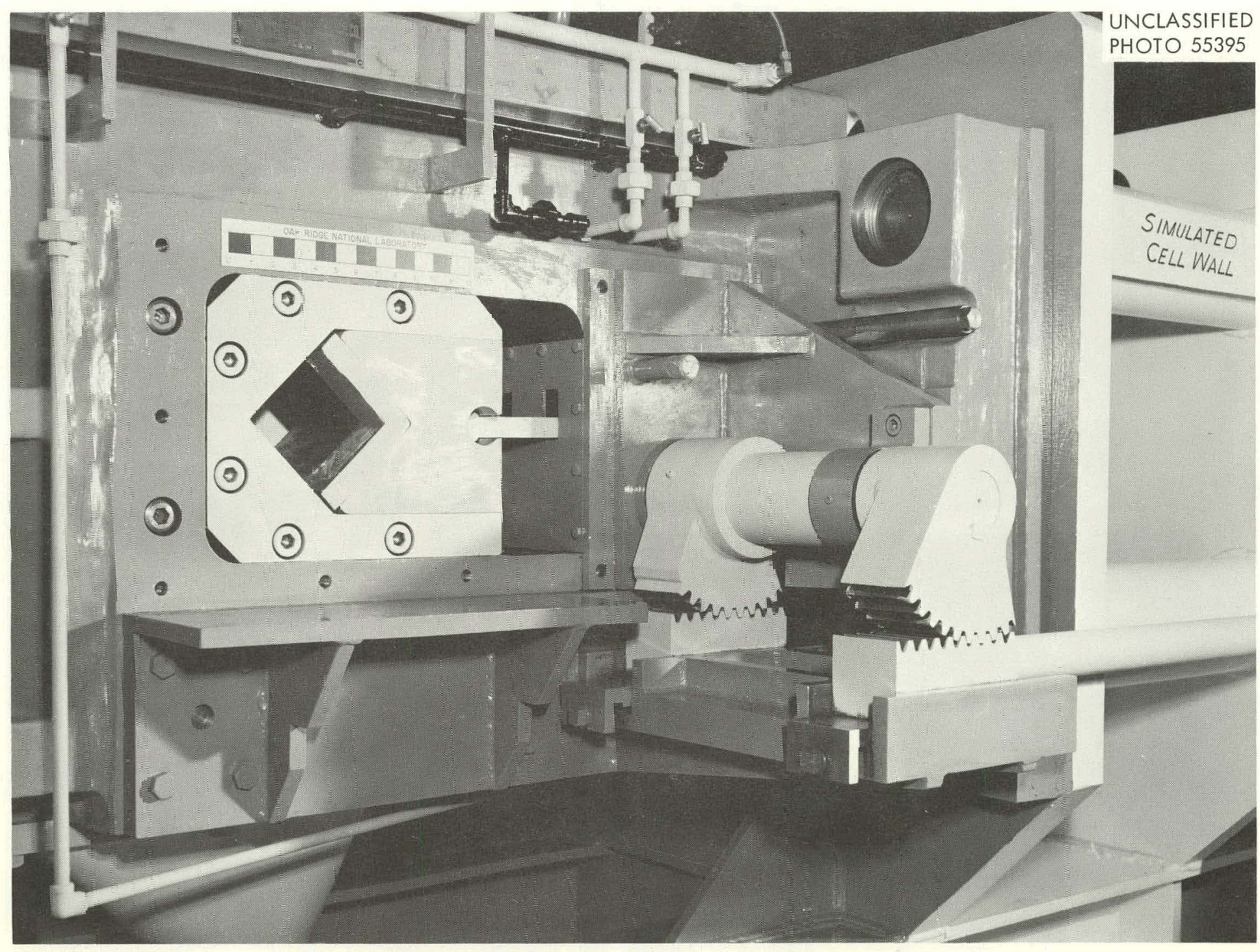

Fig. A-16. View of shear showirg gag for holding fuel element. 


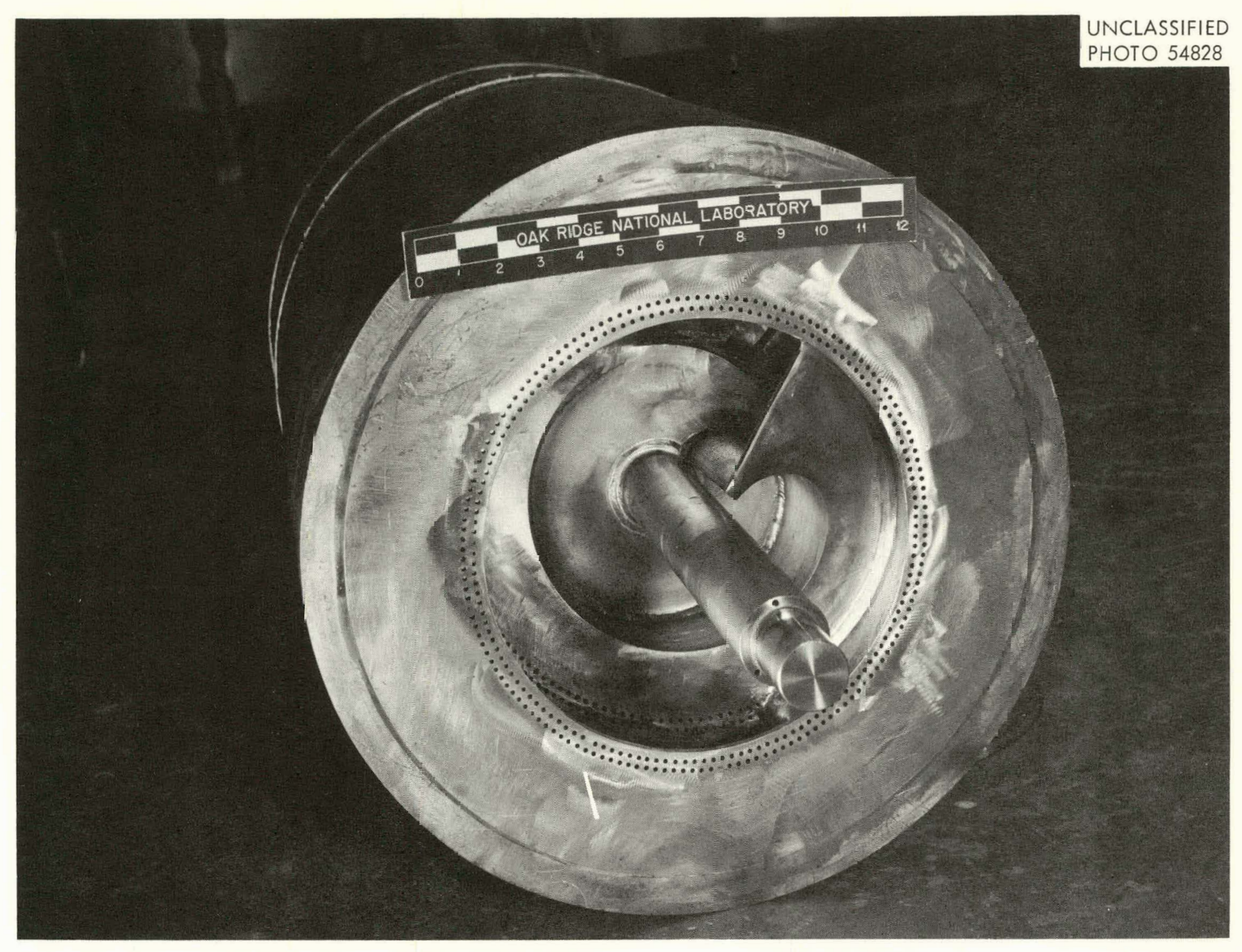

Fig. A-17. Inner drum of leacher. 


\author{
ORNL-3227 \\ UC-10 - Chemical Separations Processes \\ for Plutonium and Uranium \\ TID-4500 (17th ed.)
}

INTERNAL DISTRIBUTION

\author{
1. Biology Library \\ 2-3. Central Research Library \\ 4. Reactor Division Library \\ 5. ORIL - Y-1.2 Technical Library \\ Document Reference Section \\ 6-25. Laboratory Records Department \\ 26. Laboratory Records, ORNL R.C. \\ 27. J. B. Adams \\ 28. E. D. Arnol.t, \\ 29. A. M. Bents \\ 30. R. E. Blanco \\ 31. J. O. Blomeke \\ 32. G. E. Boyd \\ 33. J. C. Bresee \\ 34. K. B. Brown \\ 35. F. R. Bruce \\ 36. W. L. Carter \\ 37-38. F. L. Culler \\ 39. D. E. Ferguson. \\ 40. L. M. Ferris \\ 41. B. C. Finney \\ 42. J. R. Flanary \\ 43. J. H. Frye, Jr. \\ 44. T. A. Gens \\ 45. J. H. Gillette \\ 46. H. E. Goeller \\ 47. A. T. Gresky \\ 48. W. R. Grimes \\ 49. C. E. Guthrie \\ 50. C. W. Hancher \\ 51. C. S. Harrill \\ 52. A. Hollaender \\ 53. A. S. Householder \\ 54. A. R. Irvine \\ 55. R. G. Jordan (Y-12)
}


96. J. A. McBride, Idaho Chemical Processing Plant

97. J. A. Buckham, Idaho Chemical Processing Plant

98. R. Geier, Hanford Atomic Products Operation

99. Division of Research and Development, AEC, ORO

100-607. Given distribution as shown in TID-4500 (17th ed.) under Chemical Separations Processes for Plutonium and Uranium category (75 copies - OTS) 